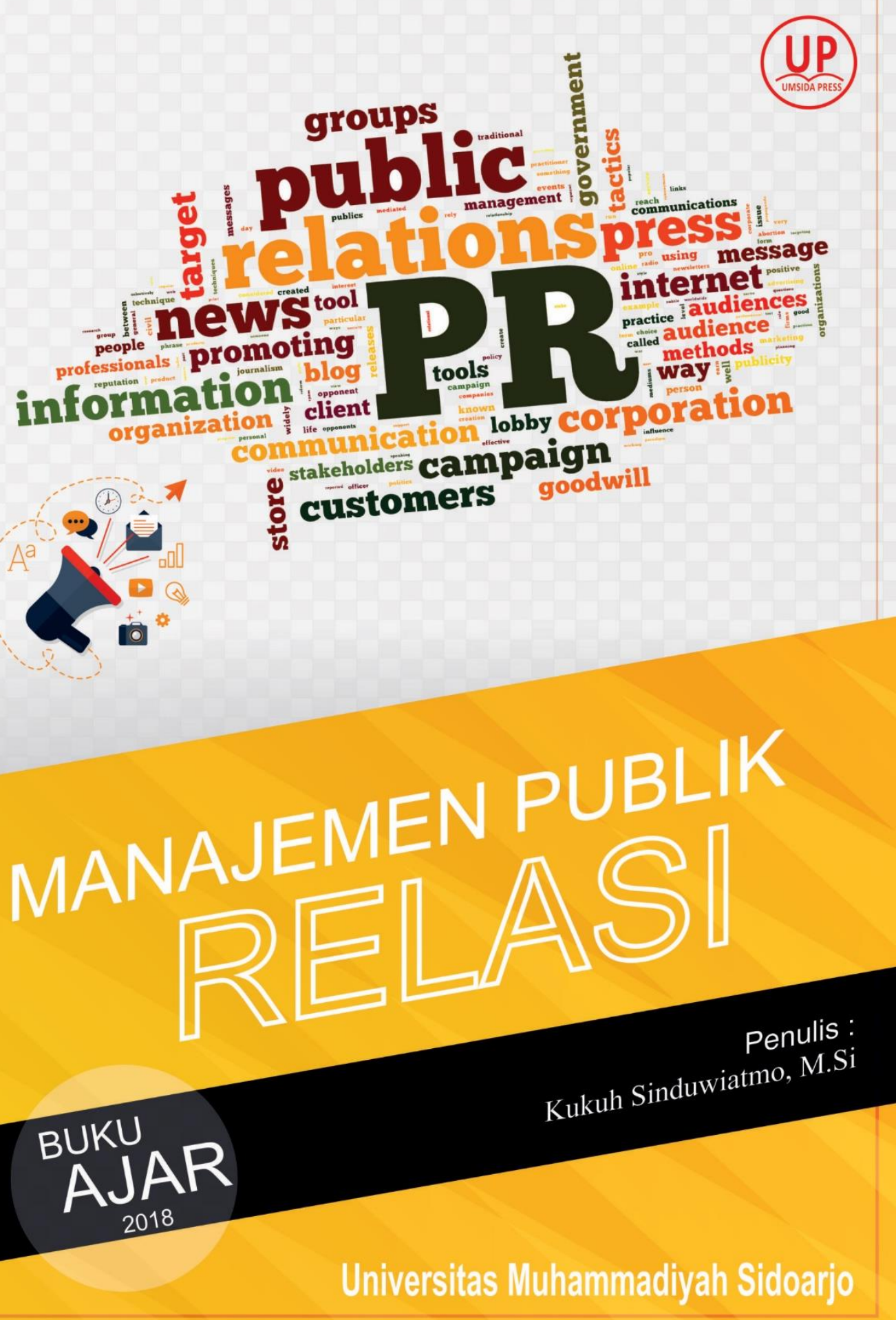




\title{
BUKU AJAR \\ MANAJEMENT PUBLIC RELATION
}

\author{
Penulis
}

Kukuh Sinduwiatmo,M.Si

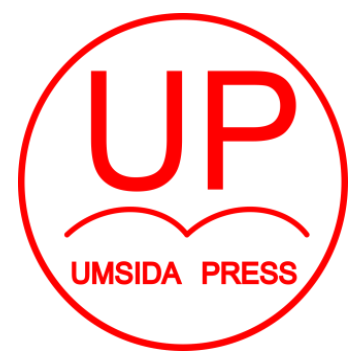

Diterbitkan oleh

UMSIDA PRESS

Jl. Mojopahit 666 B Sidoarjo

ISBN: 978-602-5914-01-0

Copyright@2018.

Authors

All rights reserved 
BUKU AJAR

\section{MANAJEMENT PUBLIC RELATION}

\section{Penulis :}

Kukuh Sinduwiatmo, M.Si

\section{ISBN :}

978-602-5914-01-0

\section{Editor :}

Septi Budi Sartika, M.Pd

M. Tanzil Multazam, S.H., M.Kn.

\section{Copy Editor :}

Fika Megawati, S.Pd., M.Pd.

Design Sampul dan Tata Letak :

Mochamad Nashrullah, S.Pd

\section{Penerbit :}

UMSIDA Press

\section{Redaksi :}

Universitas Muhammadiyah Sidoarjo

Jl. Mojopahit No 666B

Sidoarjo, Jawa TImur

Cetakan pertama, Agustus 2018

(C) Hak cipta dilindungi undang-undang

Dilarang memperbanyak karya tulis ini dengan suatu apapun tanpa ijin tertulis dari penerbit. 


\section{KATA PENGANTAR}

Alhamdulillah, segala puji bagi Allah SWT atas limpahan rahmat dan karunia-Nya, penulis dapat menyelesaikan Buku Ajar Manajement Public Relation ini. Penulis menyadari bahwa isi didalam buku ini masih banyak menyadur dari berbagai referensi dari berbagai buku, jurnal, maupun hasil penelitian terdahulu. Oleh karena itu jika terdapat kekeliruan dalam penulian sumber referensi, penulis mohon maaf yang sebesarbesarnya. Penulis sangat tertarik menulis buku ini dikarenakan Manajement Public Relation merupakan kajian yang didalamnya mengupas tentang bagaimana sebuah perusahaan tersebut mampu dan tetap tegar dalam menjalankan produktivitasnya meskipun dalam kenyataannya tak dapat dielakan lagi mengalami terjadinya sebuah krisis. Disinilah Manajement mempunyai arti penting untuk membangun kepercayaan dengan memanfaat potensi yang ada sehingga visi misi perusahaan dapat tercapai.

Disamping itu, diharapkan buku ini akan banyak membantu dalam proses belajar mengajar pada mata kuliah Manajement PR yang di ampu oleh penulis.

Akhirnya, penulis mengucapkan terimakasih yang sebesarbesarnya kepada semua yang terlah terlibat dan membantu dalam penyusunan buku ajar ini. Penulis juga mohon maaf 
yang sebesar-besarnya atas kesalahan yang terdapat dalam buku ajar ini. Sebagai upaya terus memperbaiki dan meningkatkan kualitas buku ajar ini, penulis menerima kritik dan saran yang membangun. Selanjutnya, penulis ucapkan selamat membaca.

Salam,

Penulis 
DAFTAR ISI

Halaman

Kata Pengantar

BAB I: SALAH PENGERTIAN PUBLIC RELATION

- Pengertian PR

- Tujuan dan Fungsi PR

- Ruang Lingkup Pekerjaan PR

\section{BAB II: STRATEGI MANAJEMENT PR}

- Langkah langkah strategi Manajement

- Model Strategi Manajement PR

- Membuat langkah langkah sebuah visi misi

Perusahaan

- Membuat Company Profile

BAB III: PERENCANAAN PR DAN MANAJEMENT KRISIS

- Pengelolaan Target PR

- Anantomi Krisis

- Mengelola Krisis

BAB IV: MEMANFAATKAN BUDAYA PERUSAHAAN

- Pengertian Budaya Perusahaan

- Budaya Perusahaan dan Strategi Manajement

- Bagaimana PR Memanfaatkan Budaya Perusahaan 
Halaman

\section{BAB V : MARKETING PUBLIC RELATIONS}

- Marketing Public Relations

- Konstribusi Public Relations dalam marketing

BAB VI : KUALIFIKASI PROFESI PR

- Persyaratan dasar PR

- Apakah anda memenuhi syarat

KESIMPULAN

DAFTAR PUSTAKA 


\section{BAB I}

\section{SALAH PENGERTIAN PUBLIC RELATIONS}

\section{A. Deksripsi Singkat}

Banyak orang beranggapan bahwa Public Relations merupakan bidang yang baru muncul sejak berakhirnya Perang Dunia II atau baru muncul sejak awal abad 20. Masalahnya Public Relations sudah ada sebelum Negara Amerika ada. Gagasan Public Relations sendiri bisa dikatakan sama tuanya dengan peradaban manusia.

Public Relations bukanlah usaha menciptakan suatu citra baru atau iklim pendapat umum yang menyenangkan atau mencoba memoles citra yang sudah ada. Definisi ini muncul ketika mencampuradukkan antara PR dengan pemasaran dan periklanan atau propaganda. PR merupakan pendekatan yang sangat strategis dengan menggunakan konsep-konsep komunikasi (Kasali, 2005:1).

Dalam prakteknya memang sering dijumpai salah pengertian tentang PR. Terkadang banyak orang sulit membedakan antara Public Relations dengan periklanan, pemasaran, promosi penjualan, propaganda dan publisitas. Secara umum, PR merupakan hal ihwal yang jauh lebih luas dari semua itu (periklanan, pemasaran, promosi penjualan, propaganda dan publisitas).

Banyak orang secara keliru menyamakan PR dengan fungsi manajemen lainnya (Marketing). Lowongan kerja yang 
menyebutkan posisi "perwakilan public relations" ternyata adalah posisi sales door to door atau posisi sales lewat telepon. Dalam beberapa organisasi, orang yang sama melakukan baik itu fungsi PR maupun marketing, sering kali tanpa membedakan kedua bidang tersebut. Karena kerancuan ini, beberapa orang secara keliru mengatakan bahwa kedua bidang itu tidak ada bedanya. Kerancuan juga terjadi dalam organisasi nirlaba dan agen pemerintah dimana "marketing nirlaba" dan "marketing sosial" sering kali mengacu pada pembentukan dan pemeliharaan hubungan dengan anggota, pasien dan konstituen lainnya. Dalam salah satu contoh nyata, seorang "Departemen Komunikasi Marketing" yang mengejutkannya,manajemen mengubah nama itu menjadi "Departemen Public relations" tanpa memberitahu dirinya pihak administrasi rumah sakit rupanya menganggap tidak ada masalah meletakan istilah marketing ke departemen PR. Menurut mereka, itu hanya sekedar mengubah nama saja.

\section{B. Kompetensi Dasar}

Setelah perkuliahan selesai diharapkan mahasiswa mampu dan memahami Tujuan dan Ruang Lingkup PR.

\section{Indikator}

- Mahasiswa mengetahui definisi PR

- Mahasiswa mampu menyebutkan tujuan, fungsi dan ruang lingkup pekerjaan PR 
- Mahasiswa mampu mengidentifikasi kepribadian perusahaan.

\section{I.1. SALAH PENGERTIAN TENTANG PUBLIC RELATIONS}

Dalam Praktek memang sering dijumpai salah pengertian tentang public relations. Kesalahan kesalahan itu antara lain :

\section{Public Relations adalah Personal Relations}

Sering orang menilai bahwa seseorang mempunyai kemampuan public relations karena orang itu pandai membina hubungan secara pribadi.Pengertian ini tidak salah 100\% karena seorang praktisi yang baik haruslah pandai membangun Personal Relations. Namun ini saja tidak cukup. Pendapat bahwa public relations sama dengan personal relations pernah pula muncul di kalangan praktisi yang menyatakan bahwa public relations adalah Personal relationship.

\section{Public Relations adalah Propaganda}

Memang public relations mempunyai akar yang kuat pada perang.Pada masa perang pihak yang bersengketa sering mengirim pesan yang salah kepada lawannya untuk mematahkan semangat musuh. Propaganda dilakuakn dengan tidak jujur untuk memperoleh kemenangan sepihak. Public relations sering dianggap sebagai alat propaganda oleh eksekutif yang tidak 
paham benar. Dengan itu diharapkan publik akan bersimpati kepada perusahaan dan perusahaan dapat memenangkan persaingan. Teknik tekink pemberitaan pers dan iklan dengan tidak jujur sering menyesatkan praktek public relations.

\section{Public Relations adalah Publisitas}

Pendapat inim sering tercermin dalam kegiatan public relations lembaga lembaga milik pemerintah untuk mempublikasikan kebijakan kebijakan pemerintah serta pemimpinnya. Public relations disini tak lebih dari press relations yang pekerjaan sehari harinya adalah menyusun jadwal untuk membawa wartawan mengikuti kunjungan pejabat ke daerah. Sekali lagi hal ini adalah bukan public relations. Melainkan Press relations.

\section{Public Relations adalah Iklan gratis}

Karena iklan harus dibayar, maka berita tentang perusahaan yang dimuat disuatu media dianggap sebagai iklan yang gratis. Oleh karena itu banyak praktisi pemasaran yang berupaya memanfaatkan publikasi pers untuk berpromosi. Padahal bukan itu tujuan pemuatan suatu berita. Public relatuons menggunakan pers untuk menjelaskan atau membangun citra. 


\section{Public realtions adalah menjual senyum}

Memang untuk berhasil "membujuk" orang lain , public relations membutuhkan keramahan. Namun perlu diketahui bahwa itu bukan public relations. Public relations dapat menggunakan orang lain seperti tokoh tokoh celebirtis (artis) untuk membujuk orang lain. Inti kegiatan ini sebenarnya terletak pada keahlian mengembangkan dan menjalankan strategi.

Istilah Public relations sering diartikan menjadi "Hubungan Masyarakat (HUMAS)". Sebenarnya penggunaan istilah Hubungan masyarakat ini tidak tepat. Arti kata "Public" dlam public relationsberbeda dengan kata "masyarakat" dalam hubungan masyarakat. Istilah masyarakat terlalu luas, sedangkan public (publik) hanyalah bagian dari masyarakat yang luas itu. Publik merupakan sekumpulan orang atau kelompok dalam masyarakat yang memiliki kpeentingan atau perhatian yang sama terhadap sesuatu hal. Kepentingan yang sama itulah yang mengikat anggota publik satu sama lainnya.

\section{I.2. PENGERTIAN PR}

Pengertian Public Relation - Untuk mengetahui defenisi Public Relation, kita awali dari era Ivi Lee pada tahun 1906. Ivi lee tercatat sebagai penyandang profesi public Relation Officer pertama di Amerika Serikat dan dengan keberhasilanya mengatasi berbagai persoalan krisis yang menimpa beberapa perusahaan di 
Amerika Serikat pada waktu itu melalui kiat dan strategy of public relation tersebut, maka namanya diangkat sebagai "Bapak Hubungan Masyarakat" abad ini. Sejak saat itulah masyarakat menjadi tahu keberadaan dan manfaat profesi kehumasan melalui hasil karya gemilangnya di bidang Public Relation.(Ruslan : 2005 : 5). Banyak yang mengira bahwa Public Relation hanyalah kegiatankegiatan yang tampak, tetapi kenyataannya kegiatan yang tampak oleh publik justru hanya satu tahap saja dari keseluruhan kegiatan Public Relation yang sebenarnya.

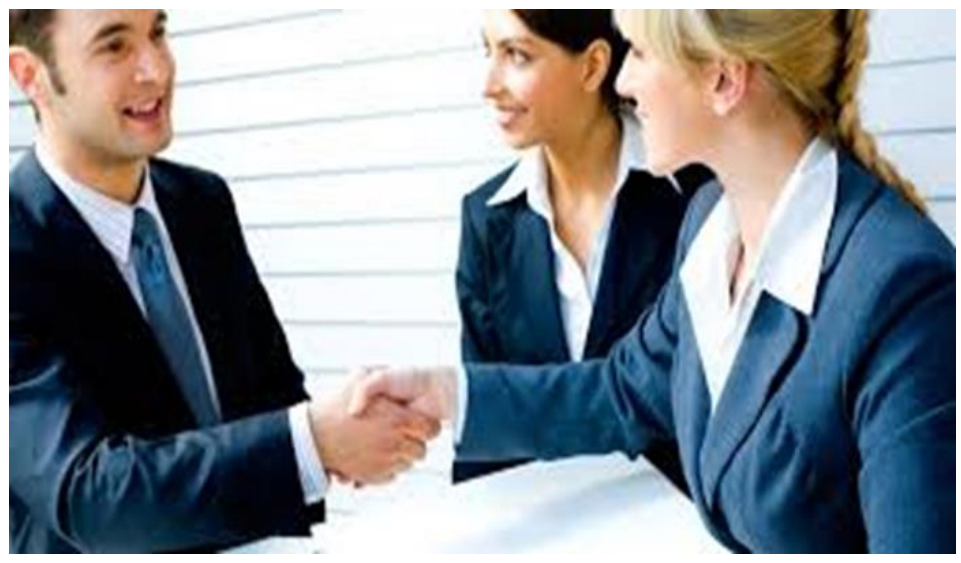

\section{Menurut Frank Jefkins (1995 : 9):}

"Public Relations adalah sesuatu yang merangkum keseluruhan komunikasi yang terencana, baik itu ke dalam maupun ke luar, antara suatu organisasi dengan semua khalayaknya dalam rangka mencapai tujuan-tujuan spesifik yang berlandaskan pada saling pengertian". 


\section{Menurut Cutlip,Center \& Broom :}

"Public Relations adalah fungsi manajemen yang membangun dan mempertahankan hubungan yang baik dan bermanfaat antara organisasi dengan publik yang memengaruhi kesuksesan atau kegagalan organisasi tersebut".

\section{Menurut Grunig \& Hunt :}

"Public relations adalah manajemen komunikasi antara organisasi dan publiknya".

\section{I.3. TUJUAN DAN FUNGSI PR}

Fungsi utama $\boldsymbol{P} \boldsymbol{R}$ adalah menumbuhkan dan mengembangkan hubungan baik antarlembaga (organisasi) dengan publiknya, internal maupun eksternal dalam rangka menanamkan pengertian, menumbuhkan motivasi dan partisipasi publik dakam upaya menciptakan iklim pendapat (opini publik) yang menguntungkan lembaga organisasi.

Aktifitas public relations adalah menyelenggarakan komunikasi timbal balik (two ways traffic communications) antara lembaga dengan publik yang bertujuan untuk menciptakan saling pengertian dan dukungan bagi tercapainya tujuan tertentu, kebijakan, kegiatan produksi, demi kemajuan lembaga atau citra positif lembaga bersangkutan. Kegiatan public relations sangat erat kaitannya dengan pembentukan opini publik dan perubahan sikap dari masyarakat. Jika menghadapi situasi yang genting 
(crutial) seperti timbul masalah, konflik, pertikaian hingga terjadi suatu krisis, maka public relations wajib menjelaskan secara jujur dan terbuka (open communication). Dikarenakan di satu pihal public relations bertindak sebagai perantara (mediator) dan di lain pihak memiliki tanggung jawab sosial (social responbility) yang harus memegang teguh baik etika maupun kejujuran.

Sedangkan Cutlip \& Center menyebut fungsi Public relations sebagai berikut :

1. Menunjang kegiatan manajemen dan mencapai tujuan organisasi.

2. Menciptakan komunikasi dua arah secara timbal balik dengan menyebarkan informasi dari perusahaan kepada publik dan menyalurkan opini publik kepada perusahaan.

3. Melayani publik dan memberikan nasehat kepada pimpinan perusahaan untuk kepentingan umum.

4. Membina hubungan secara harmonis anatara perusahaan ,baik internal maupun eksternal.

Tujuan utama kegiatan public relations adalah membangun kredibilitas dan membangkitkan motivasi bagi para pemangku 
kepentingan (stakeholders) perusahaan guna meminimalkan biaya pengeluaran proses transfer komunikasi.

Tujuan Public Relations dapat dikelompokkan sebagai berikut:

\section{A. Perfomance Objective}

PR merupakan kegiatan komunikasi untuk mempresentasikan citra perusahaan kepada publiknya, melaksanakan serangkaian kegiatan untuk membentuk dan memperkaya identitas dan citra perusahaan dimata stakeholders.

\section{B. Support of Customer Market Objective}

Kegiatan PR dapat digunakan untuk mengidentifikasi permasalahan yang timbul sehubungan dengan kegiatan komunikasi yang dilaksanakann oleh perusahaan dengan menitikberatkan pembahasan pada identifikasi tingkat kesadaran konsumen, sikap dan persepsi konsumen terhadap produk tayangan yang ditawarkan perusahaan. Hasil identifikasi tersebut kemudian dapat dijadikan sebagai bahan pertimbangan perusahaan untuk menerapkan strategi pendekatan yang sesuai.

\section{I.4. RUANG LINGKUP PR}

Ruang Lingkup Pekerjaan Public Relations

Secara sederhana pekerjaan yang biasa dilakukan public relations dapat disingkat menjadi PENCILS, yaitu : 
a. Publication \& publicity, yaiotu mengenalkan perusahaan kepada publik.(misal: membuat tulisan yang disebarkan ke media, newsletter,artikel dII)

b. Events, mengorganisasi event atau kegiatan sebagai upaya membentuk citra.(misal: stasiun televisi SCTV Award,program televisi yang dinilai masyarakat ngetop akan mendapat penghargaan SCTV).

c. News, pekerjaan seorang public relations adalah menghasilkan produk-produk tulisan yang sifatnya menyebarkan informasi kepada publik.( misal : press release,berita,newsletter dll. Karena itu dituntut menguasai teknik teknik menulis)

d. Community involvement, public relations mesti membuat program-program yang ditujukan untuk menciptakan keterlibatan komunitas atau masyarakat sekitarnya (misal : Hotel santika setiap HUT RI mengadakan perlombaan yang juga diikuti masyarakat sekitar hotel,Public relations juga diharapkan dapat memposisikan perusahaan sebagai bagian dari komunitas. Diharapkan akan muncul perasaan memiliki terhadap perusahaan (sense of belonging) dalam diri komunitasnya)

e. Identity Media, merupakan pekerjaan public relations dalam membina hubungan dengan media (pers). Sangat penting 
untuk memperoleh publisitas media. Media adalah mitra kerja abadi Public relations. Media butuh Public relations sebagai sumber berita dan public relations butuh media sebagai penyebar informasi serta pembentuk opini publik.

f. Lobbying, public relations sering melakukan upaya persuasi dan negoisasi dengan berbagai pihak. Keahlian ini tampak dibutuhkan (misal : Pada saat terjadi krisis manajemen untuk mencapai kata sepakat diantara pihak yang bertikai.

g. Social investement, pekerjaan public relations untuk membuat program-program yang bermanfaat bagi kepentinagn dan kesejahteraan sosial. (Misal ; Program public relations "Trans TVPeduli Aceh" yang memberi bantuan dana dan pembuatan rumah bagi korban bencana Tsunami akhir 2004 lalu. Termasuk disini adalah program Cooparate Social Responsibility (CSR).

\section{LANGKAH LANGKAH MENYUSUN PROGRAM PUBLIC RELATIONS}

\section{MENENTUKAN MASALAH}

Langkah awal menyusun program public relation adalah menentukan hakikat masalah yang harus diatasi oleh praktisi. Dalam kehidupan perusahaan, pengenalan masalah public relations kadang kala lebih sulit daripada yang diperkirakan. Terlalu sering terjadi seorang pimpinan eksekutif begitu larut dalam tekanan langsung agar perusahaan mendapatkan perolehan 
keuntungan yang memuaskan. Dalam keadaan demikian, ia tidak menyadari bahwa telah timbul masalah public relations di lingkungan organisasi-satu masalah yang dalam jangka panjang mungkin sungguh-sungguh mengancam inti profitabilitas yang senantiasa diupayakan oleh pimpinan eksekutif tersebut.

Dengan menggunakan antena yang sensitif yang dikembangkan untuk mendeteksi suasana hati masyarakat dan karyawan, seorang direktur public relations sebuah perusahaan dan/atau firma penasihat public relations harus mengenal masalah ketika sedang berkembang. Kemudian pakar public relations itu harus melaporkan kepada manajemen puncak bahwa telah terjadi masalah yang sedang bergerak maju sehingga dibutuhkan perhatian secepatnya.

\section{MENENTUKAN SASARAN}

Agar kampanye berjalan dengan lancar, praktisi harus bertanya, "Persisnya apa yang hendak kita capai?" Semakin spesifik jawabannya, semakin baik prospek keberhasilannya dan semakin besar potensinya untuk mengukur hasil. Sasaran yang kabur seperti, "Mendapatkan publisitas untuk produk baru kita," relatif tidak berarti. Target pentingnya adalah jumlah unit yang terjual, bukan ukuran arsip kliping pers. Secara khusus penting bahwa sasaran public relations melengkapi dan memperkuat sasaran organisasi. Profesor David Dozier dan Universitas Negeri 
San Diego mengungkapkan poin ini dengan baik dalam sebuah artikel di Public Relations Review, katanya: "Seleksi sasaran public relations yang strategis dan saksama yang dikaitkan dengan pertumbuhan dan pelestarian organisasi akan mampu membuat program public relations sebagai kegiatan manajemen yang hidup."

\section{MENENTUKAN KHALAYAK.}

Segera setelah sasaran ditetapkan, praktisi harus menentukan khalayak atau khalayak apa saja yang akan menjadi sasaran kampanye. Tepatnya siapa yang akan mendapat informasi atau dimotivasi oleh kampanye? Tujuan menentukan khalayak ini semata-mata untuk mencegah pemborosan usaha dan rupiah. Beberapa kampanye dapat diarahkan pada masyarakat umum. Kampanye lain harus diarahkan pada khalayak yang lebih terfokus dan lebih kecil. Membuang sejumlah besar dana untuk mendidik masyarakat luas mengenai isu-isu yang tidak mengena pada kebutuhan mereka adalah nonproduktif. Menargetkan pesan pada khalayak yang sesuai lebih menjanjikan hasil yang prima.

\section{MERENCANAKAN PROGRAM}

Seperti disebutkan dalam bahasan mengenai cara-cara menentukan dan menghubungi khalayak, seorang praktisi mempunyai berbagai macam pilihan yang ada, ketika sedang 
merencanakan program. Media komersial-tulisan, lisan, dan visual-memberikan cara-cara menyampaikan pesan program. Yang termasuk dalam media ini adalah surat kabar, majalah, buku, radio, televisi, dan film-film bioskop. Di samping itu, pesan dapat disajikan melalui materi sambutan, pertemuan, pita video, dan materi tertulis, serta materi dengar pandang yang disiapkan oleh departemen public relations atau biro konsultasi selaku penyelenggara program. 


\section{BAB II}

\section{SRATEGI MANAJEMEN PR}

\section{A. Deskripsi Singkat}

Seorang Praktisi Public Relations dalam tugasnya akan melaksanakan suatu aktivitas yang bernama Manajemen Public Relation, manajemen ini merupakan terapan dari ilmu manajemen dasar yang diimplikasikan di dunia public relations. Sebelum melangkah lebih jauh untuk mengetahui manajemen public relations, maka seharusnya kita sedikit memahami pengertian apa yang dimaksud dengan manajemen. Menurut George R. Terry (1972) Sebuah proses yang khas dan terdiri dari tindakan seperti pemasaran, pengorganisasian, pengaktifan dan pengawasan yang dilakukan untuk menentukan serta mencapai sasaran.

Istilah Strategic mangement sering disebut pula rencana strategis atau rencana jangka panjang perusahaan. Dalam suatu rencana strategis perusahaan menetapkan garis garis besar tindakan strategis yang akan diambil dalam kurun waktu tertentu ke depan. Berapa lama waktu yang akan dicakup tentu amat bervariasi. Di masa lalu para ahli menyebut sekitar 25 tahun, tetapi dewasa ini jarang sekali perusahaan yang berani menetapkan arahnya untuk 25 tahun ke depan. Sebagian besar membuatnya dalam 5-10 tahun. Alasannya cukup masuk akal, yakni perubahan yang terjadi belakangan ini sangat sulit diterka 
arahnya. Masing masing perubahan itu saling kait mengait, sehingga perkiraan terjatuh yang dapat diduga menjadi amat terbatas. Untuk melihat kedepan perusahaan perlu melihat ke belakang, yakni hal hal yang telah dicapai dimasa lalu, harapan yang dijanjikan dari prestasi itu dan persepsi yang muncul dari lingkungannya. Seorang praktisi public relations tidaklah dibenarkan mengabaikan pelaksanaan penyusunan rencana jangka panjang ini. la perlu turut aktif mengobservasi pendapat dan harapan tersebut. Karena prosesnya melibatkan banyak pihak, suatu rencana jangka panjang yang berhasil disatukan sering disebut pula suatu "konsensus".

Untuk mengkonstribusi rencana jangka panjang itu, praktisi Public Relation dapat melakukan langkah langkah sebagai berikut :

1. Menyampaikan fakta dan opini, baik yang beredar didalam maupun di luar perusahaan. Bahan bahan itu dapat diperoleh dari kliping media massa dalam kurun waktu tertentu dengan melakukan bahan yang diopublikasikan perusahaan, serta melakukan wawancara tertentu dengan pihak yang berkepentingan atau dianggap penting.

2. Menelurusi dokumen resmi perusahaan dan mempelajari perubahan yang terjadi secara historis. Perubahan ini umumnya disertai dengan perubahan sikap perusahaan terhadap publiknya dan sebaliknya. 
3. Melakukan Analisis SWOT ( Strengths (krekuatan); Weaknesses (kelemahan); Opportunities (peluang); Threats ((ancaman))

\section{B. Kompetensi Dasar}

Mahasiswa mampu memahami definisi startegi Manajement PR,Model model Strategi serta dapat mengidentifikasi Publik dalam PR.Mahasiswa juga dapat membuat langkah langkah dalam membuat visi dan misi perusahaan

\section{Indikator}

- Mahasiswa mampu memaparkan tugas tugas PR

- Mahasiswa mampu mejelaskan tentang definisi strategi manajemen PR

- Mahasiswa dapat mengidentifikasi Publik dalam PR

- Mahasiswa dapat membuat langkah langkah sebuah visi dan misi Perusahaan

\section{LANGKAH LANGKAH STRATEGI MANAJEMENT}

Strategi management juga dimaksudkan agar perusahaan atau organisasi dadpt dikendalikan dengan baik untuk mencapai tujuannya. Oleh karena itu hal yang paling dasar bagi manajer di di dalam perusahaan adalah mengetahui dengan pasti arah yang sedang dituju oleh perusahaan dan arah bagian yang dipimpinnya. Bayangkan, saudara suatu ketika merayakan liburan bersama 
dengan keluarga dengan menumpang sebuah kapal pesiar. Kapal berangkat dari pelabuhan di Tanjung Perak surabaya. Tapa melkuakn komunikasi kepada anak anak, saudara menganggap semua tahu ke mana kapal akan mendarat. Katakkanlah kapal akan menuju ke Fukuoka, sebuah kota kecil di pulau Kyusu , 950 km sebelah selatan Tokyo. Tetapi benarkah mereka (anak anak) tahu bahwa kapal akan menuju Jepang? Dan dimana sasaran antarannya ?.

Perjalanan sebuh perushaan menuju sarsarannya adalah lebih dari sekedar kepergian dengan kapal pesiar, karena di sepanjang perjalanannya banyak perubahan yang mungkin timbul. Mungkin nahkodanya diganti ditengah jalan, mungkin para awaknya mundur, mungkin ada badai sehingga kapal harus berlabuh di tempat lain atau mengkin ada sasaran lain yang lebih menarik. Yang jelas perjalanan sebauh perusahaan lebih banyak menemui hal hal yang tidak pasti di tengah perjalanannya ketimbang mengemudikan sebuah kapal. Lebih jauh, para awak kapal dan nahkoda lebih sering rteropaku dengan hal hal operasional dari hari ke hari daripada memikirkan arah kapalnya dan mempertimbangkan kakpsitas yang dimiliki. Yang llebih celaka lagi, mereka semua mempunyai mimpi yang berbeda beda kendati sudah tidur di atas kapal yang sama. Dan mereka menganggap bahwa mimpi mereka sama dan seakan akan orang lain mengerti apa isi mimpinya. 
Itu semua tidak benar. Dalam sebuah perusahaan atau kapal yang tengah berlayar, bahkan dimana lokasi perusahaan hari ini berada saja, tidak banyak yang tahu. Strategic Management memulai pekerjaannya dengan mencari tahu dimana lokasi perusahaan atau organisasi itu berada pada hari ini dan meyatukan mimpi mimpi itu di dalam suatu kesepakatan bersama. Mimpi itu dalam istilah Strategic Management disebut Mission.

Public Relations, sebagai salah satu komponen kapal itu, diadakan untuk tujuan startegis, yaitu untuk membaca rintangan yang muncul dari luar ( ketentuan pemerintah yang mematikan, ketidakpahaman karyawan atas sikap penduduk di sekitar pabrik sehingga penduduk bersikap melawan, tindakan pesaing, boikot dari konsumen sampai pada kesalahan perusahaan yang dibuat tanpa sengaja terhadap publiknya) maupun dari dalam (pemogokan karyawan, pengrusakan, sikap tidak terpuji dll) agar kapal dapat berlayar dengan selamat ke tujuannya. Public Relations memberi sumbangan yang sangat besar bagi perusahaan dengan mengembangkan hubungan hubungan (relations) yang harmonis dengan stakeholdersnya agar perusahaan dapat mengembangkan kemampuannya mencapai missionnya.

Menurut Pearce dan Robinson, mengembangkan langkah langkah Strategic Management sebagai berikut : 
1. Menentukan mission perusahaan. Termasuk didalamnya adalah pernyataaan yang umum mengenai maksud pendirian (Purpose), filosofi dan sasaran (goals).

2. Mengembangkan Company Profile yang mnecerminkan kondisi intern perusahaan dan kemampuan yang dimilikinya.

3. Penilaian terhadap lingkungan ekstern perusahaan, baik dari segi semangat kompetitif maupun secara umum.

4. Analisis terhadap peluang yang tersedia dari lingkungan (yang melahirkan pilihan pilihan )

5. Indentifikasi atas pilihan yang dikehendaki yang tidak dapat digenapi untuk memenuhi tuntutan misi perusahaan.

6. Penilihan strategi atas objektive jangka panjang dan garis besar strategi yang dibutuhkan untuk mencapai objektive tersebut.

7. Mengembangkan objektive tahunan dan rencana jangka pendek yang selaras dengan objektive jangka panjang dan garis besar strategis.

8. Implementasi atas hasil hal hal diatas dengan menggunakan sumber yang tercantum pada budget (anggaran) dan mengawinkan rencana tersebut dengan sumber daya manusia, struktur teknologi dan sistem balas jasa yang memungkinkan.

9. Review dan evaluasi atas hal hal yang telah dicapai dalam setiap periode jangka pendek sebagai suatu proses untuk melakukan kontrol dan sebagai input bagi pengambilan keputusan di masa depan (Kasali,1994-43). 


\section{II.1 MEMBUAT LANGKAH LANGKAH SEBUAH VISI MISI}

PERUSAHAAN

\section{Langkah-langkah membuat visi misi :}

1. Buatlah SWOT (Strength, Weakness, Opportunity, Threat) organisasi terlebih dahulu.Yang perlu diperhatikan sebelumnya adalah ilmu tentang pembuatan SWOT sendiri. Langkah selanjutnya dalam pembuatan SWOT adalah :

\section{Meringkas SWOT}

Meringkas disini maksudnya : pilih kata kunci pada tiap poin di SWOT, setelah itu susun dan kelompokkan kata kunci-kata kunci tadi. Kata kunci pada poin S dikelompokkan dengan poin $\mathrm{O}$, sedangkan kata kunci pada poin $\mathrm{W}$ dengan poin $\mathrm{T}$.

\section{Menentukan visi}

Setelah langkah 2 selesai, artinya kamu sudah mendapatkan 2 grup kata kunci.

Nah, Visi adalah : Kalimat pendek yang mudah diingat dan memotivasi ketika dibaca yang isinya menguatkan si group dan menekan group .

\section{Menentukan Misi}

Definisi misi yang terdoktrin dalam benak saya sampai sekarang adalah

"Misi itu langkah2 untuk mewujudkan visi" 


\title{
CONTOH :
}

\section{VISI \& MISI PERUSAHAAN MANUFACTURING}

\author{
A. TOYOTA ASTRA MOTOR - VISI DAN MISI \\ PT Toyota-Astra Motor (TAM) sebagai importir, distributor dan \\ produksi kendaraan Toyota di Indonesia
}

\section{VISI}

Menjadi perusahaan otomotif yang paling sukses dan dihormati di kawasan Asia Tenggara dengan memberikan pengalaman terbaik dalam kepemilikan kendaraan

\section{MISI}

1. Secara berkesinambungan menyediakan produk dan jasa yang berkualitas tinggi serta memenuhi kebutuhan pelanggan melalui program pemasaran yang terbaik.

2. Mengembangkan karyawan yang berkompeten dengan menciptakan lingkungan kerja yang baik untuk mendukung tercapainya kepuasan pelanggan.

3. Memperkuat kolaborasi dengan produsen, dealer utama dan dealer-dealer melalui komunikasi dan kerjasama yang lebih baik. 4. Untuk mengembangkan operasi perusahaan yang sehat dalam segala aspek, misalnya pemenuhan peraturan, lingkungan dan lain-lain. 


\section{II.2 MEMBUAT COMPANNY PROFILE}

\section{A. FUNGSI COMPANY PROFILE}

1. Represenatsi Perusahaan

Company Profile adalah : Gambaran tentang perusahaan.Bisa juga dianggap mewakili peusahaan sehingga publik tidak perlu bersusah payah mencari informasi tentang perusahaan. Dapat juga digunakan sebagai alat membangun citra agar berbagai kelompok penekan dalam masyarakat mempunyai pemahaman yang benar tentang perusahaan.

2. Bisa digunakan untuk melengkapi komunikasi lisan demi terciptanya mutual understanding.

3. Menghemat waktu transaksi. Pihak pihak lain yang berkaitan dengan perusahaan, produk, pasar, visi, misi, posisi keuangan dll. Hal itu didapat dipelajari melalui company profile sebelum dan sesudah pertemuan.

4. Membangun identitas dan citra korporat. Company profile yang dikemas menarik, detail, jelas dan mewah mencerminkan wajah perusahaan dimata publik sebagai perusahaan yang besar dan bonafide.

\section{B. ISI COMPANY PROFILE}

Banyak hal yang bisa ditulis dalam company profile. Tetapi, secara umum isi COMPANY PROFILE mencakup : 
1. Sejarah Perusahaan, mencakup antara lain: pendiri perusahaan, jajaran direksi, asal muasal, proses perkembangan, dll.

2. Filosofis perusahaan, bisa disebut pandangan atau ideologi dasar perusahaan.

3. Budaya Perusahaan, adalah nilai nilai kunci dan konsep bersama yang membentuk citra anggota organisasi terhadap organisasinya. (misal: etos kerja tinggi, maju untuk semua, makan tidak makan yang penting kumpul dsb.

4. Sambutan dari pimpinan (Dirut atau komisarisUtama) tentang segala hal yang sangat berpengaruh pada aktivitas perusahaan dan rencana jangka panjang.

5. Identitas perusahaan, termasuk disini logo, uniform, interior gedung dan kantor, kualitas cetakan atau kualitas audiovisual company profile.

6. Visi, Misi, strategi perusahaan, termasuk komitmen perusahaan untuk meraih kemajuan. Ini menunjukan bahwa opersioanal perusahaan dilaukan tidak semabrangan, tetap melalui perencanaan yang matang dan berkesinambungan. Sebagai jaminan masa depan bisnis yang berkelanjutan. Pada akhirnya menciptakan kepercayaan publik, bahwa masa depan perusahaan 
terjamin. Penting misalnya untuk meraih kepercayaan lembaga keuangan.

7. Alamat cabang/-cabang. Semakin banyak cabang perusahaaan dibeberapa wilayah menunjukan jalur distribusi yang merata. Pada akhirnya mencerminkan kebesaran dan prestise perusahaan.

8. Gambaran tentang SDM. Ceritakan orang orang dibalik operasional perusahaan, siapa saja figur pengendali dijajaran manajemen termasuk tokoh tokoh berpengaruh di masyarakat yang berkaitan dengan perusahaaan. Ini memberi keyakinan pada publik bahwa perusahaan dikelola tangan tangan yang handal.

9. Sistem pelayanan dan fasiliitas yang disediakan. Dalam persaingan ketat dewasa ini, pelayanan pelanggan memegang kunci strategis. Gambarkan kelebihan perusahaaan dari sisi pelayanan yang membedakan dengan kompetitor.

10. Prestasi dari keunggulan perusahaan, termasuk segala hal yang telah dilakukan perusahaan untunk kepentingan masyarakat. Masyarakat menuntut bukanhanya kualitas produk atau jasa, tetapi juga apa yang bisa dilakukan perusahaan dalam upaya meningkatkan kualitas kehidupan masyarakat. Misal program peduli lingkungan sebagai wujud tanggung jawab perusahaan (CSR) . 
11. Laporan perkembangan perusahaan (Annual Report) termasuk informasi laba rugi perusahaan. Ini adalah upaya menjelaskan kesehatan perusahaan.

12. Deskripsi tentang produk produk dan jasa utama yang ditawarkan . termasuk gambaran tentang pasar, lokasi pabrik, distribtuor, market share, grafik pertumbuhan usaha dsb.

13. Program pengembangan di masa datang. Termasuk pelatihan pelatihan, rencana pengembangan produk, pengembangan pasar dsb.

\section{GAMBARAN TENTANG KESEHATAN PERUSAHAAN}

Memang gambaran tentang kesehatan suatu perusahaan akan terlihat dalam laporan keuangan perusahaan. Namun pencantuman laporan keuangan secara apa aadanya sering menimbulkan kesalahpahaman, sebab para analisis mempunyai rumusan sendiri untuk menganlisis kesehatan perusahaan. Misalnya, ada pihak yang mementingkan segi jangka pendek, dan ada pula pihak yang mementingkan segi jangka panjang. Ada yang mementingkan likuiditas dan ada yang mengutamakan profitabilitas. Masing masing analis mempunyai angka kewajaran sendiri sendiri.

Oleh karenanya, diarankan agar gambaran kesehatan perusahaan dari segi keuangan ini disajikan secara terpisah, yakni 
dalam laporan tahuanan (Annual Report). Dlam laporan keuangan tersebut perlu dicantumkan hal hal sebagai berikut :

1. Penjelasan atas kegiatan penting dalam bebrapa tahun belakangan ini, khususnya kepentingan organisasi.

2. Keterangan mengenai kebijakan akuntansi dan dasar dasar yang dipakai.

3. Notes atau footnotes dari laporan keuangan.

Karena gambaran yang lebihn mendetail dari prestasi keuangan perushaaan itu dicantumkan secara terpisah dalam laporan yang lain (Annual report), perlu dicari cara lain agar pembaca dapat memahami bahwa perusahaan cukup sehat (bila ia sehat) melalui company profile. Cara ini disebut, Nonfinancial Disclosure yang dapat berarti :

1. Deskriptif naratif, fakta atau opini yang tidak secara langsung menjelaskan dalam bentuk moneter, atau

2. Informasi informasi kuantitatif yang disajikan dalam bentuk yang non moneter. Misalnya, Pencantuman jumlah pekerja, beserta tingkat rata rata upahnya (take home pay) per lokasi, grafik pertumbuhan usaha, market share, sumber sumber pembiayaan (persentase) dsb.

3. Suatu perkembangan yang sangat menarik justru menunjukan bahwa perusahaan besar, mencoba menyajikan data selengkap lengkapnya sekalipun tidak diwajibkan secara hukum. Perusahaan perusahaan 
internasional yang melakukan hal itu umumnya beranggapan bahwa manfaatnya tetap lebih banyak ketimbang buruknya, khususnya dalam kompetisi global untuk memperoleh/ menyalurkan dana investasi dan menarik manajer profesional dari perusahaan lain. Selain itu ada anggapan dikalangan para analis dan manajer berpendidikan bahwa ada banyak hal penting tidak dicantumkan dalam company profile, itu berarti ada sesuatu yang kurang sehat yang dirasakan layak disembunyikan.

\section{C.PENDEKATAN DALAM MENYUSUN COMPANY PROFILE}

Company Profile yang baik selalu mempertimbangkan hal hal sebagai berikut :

1. Identitas Perusahaan, Perusahaan tidak hanya terbatas pada logo atau atribut fisik belaka (bentuk eksterior atau interior bangunan, iklan dll), melainkan juga konsistensi pemilihan warna dan karakter cetaan. Karakter ceetakan diwakili oleh desain cetakan tesrebut.

2. Budaya Perusahaan, Akar dari identitas perusahaan sebenarnya terletak pada budaya perusaahaan. Maka company Profile yang baik dapat menerjemahkan budaya perusahaan secara konsisten. 
3. Objective Company Profile, Bila saudara sebagai seorang Public Relations Officer (PRO) mengajukan proyek usulan untuk menyusun company profile, maka saudara perlu menentukan Object Company Profile tersebut. Suatu objective yang baik harus beranjak dari objective perusahaan secara menyeluruh dan objective pada divisi yang membawahi kegiatan PR.

4. Audience, Audience atau khalayak saaran penyebaran company profile hrus jelas. Umumnya company profile ditujukan keoada piahk pihak diluar perusahaan seperti pemerintah, lembaga, kemasyarakatan,pemasok, penyalur, calon investor, calon mitra usaha, pers, konsumen besar (pembeli institusi) dan sebagainya. Karena kepentingan masing masing pihak berbeda, tekanan isi company profile jelas berbeda pula untuk setiap khalayak sasaran.

Umunya kehadiran company profile suatu perusahaan menjadi alat "keterbukaan" (disclouser) perusahaan. Makna keterbukaan dalam arti lebih luas adalah penyebaran segala bagian informasi mengenai perusahaan. Namun hal ini sering berbenturan dengan kepentingan bagian keuangan perusahaan yang merasa perlu merahasiakan kondisi keuangan perusahaan. Alasannya jelas, gambaran tentang sehat atau tidaknya perusahaan akan tersirat 
dalam laporan keuangan perusahaan. Umumnya laporan keuangan baru bisa disajikan keluar bila ada kewajiban keuangan perusahaan pada pihak yang berkepentingan, seperti bank, lembaga keuangan ( asuransi,dana pensiun) atau [erusahaan yang melepas sahamnya di bursa saham.

\section{Catatan :}

Company Profile merupakan salahsatu alat perusahaan untuk membangun citra di masyarakat. Sebagai alat komunikasi, komunikasi lisan akan jauh lebih efektif darpada dokumen tertulis. Namun demikian company profile yang disajikan secara tertulis mempunyai beberapa kelebihan :

1. Pihak yang berkepentingan dapat mengendapkan perasaannya ketika membaca profile perusahaan.

2. Dapat berfungsi sebagai referensi karena komunikasi lisan mempunyai bebabn kesalahan.

3. Mempersingkat waktu transaksi. Pihak pihak yang bersangkutan tidak perlu menanyakan secara detail tentang perusahaan, produk, psasr, misi, visi, diversifikasi dan sebagianya. Hal itu dpat dipelajari dalam company profile sebelum atau setelah pertemuan.

4. Menunjukan karakter atau kepribadian perusahaan. 
5. Dapat digunakan sebagai alat untuk membangun citra agar berbagai kelompok penekan dalam masyarakat mempunyai pemahaman yang benar tentang perusahaan.

\section{D.MEDIA COMPANY PROFILE}

Company Profile dalam bentuk cetak mempunyai keunggulan dibanding dengan media audiovisual dan internet (website). Keunggulan tersebut antara lain :

1. Terdokumentasi dan terekam. Publik bisa secara mudah membawa dan menyimpannya di rumah. Media audiovisual maupun internet harus menggunakan alat khusus (misalnya : disc atau video) untuk dapat merekam atau mendokumentasikan.

2. Dapat diulang ulang. Company Profile dapat dibaca berkali kali sehingga memudahkan daya ingat. Orang harus merekam dahulu untuk dapat melihat video atau harus ke warung internet membaca atau melihat company profile via website.

3. Lebih luas jangkauannya. Company Profile bentuk cetak dimungkinkan dapat menjangkau publik secara luas. Semuaorang bisa membacanya dengan mudah. Sedangkan audiovisual dan website sasarannya lebih terbatas. 


\section{KESIMPULAN ;}

Company profile merupakan salah satu alat perusahaan untuk membangun citra di masyarkat. Sebagai alat komunikasi, komunikasi lisan akan jauh lebih efektif daripada dokumen tertulsi. Namun demikian Company profile yang disajikan secara tertulis mempunyai beberapa kelebihan :

1. Pihak berkepentingan dapat mengendapkan perasaannya ketika membaca profile perusahaan.

2. Dapat berfungsi sebagai referensi (bahan rujukan) karena komunikasi lisan mempunyai beban kesalahan.

3. Mempersingkat waktu transaksi. Pihak pihak yang bersangkutan tidak perlu menanyakan secara detail tentang perusahaan, pproduk, pasar, misi, visi,dsb. Hal itu dapat dipelajari dalam company profile sebelum dan sesudah pertemuan.

4. Menunjukan karakter atau kepriobadian perusahaan .

5. Dapat digunakan sebagai alat untuk membangun citra agar berbagai kelompok penekan dalam masyarakat mempunyai pemahaman yang benar tentang perusahaan .

Company profile tidak perlu tampil terlamlpau mewah dengan isi yang terlalu padat. la cukup tampil sederhana sesuai dengan 
kemampuan perusahaan. Yang terpenting inforasi yang disajikan adalah benar dan sesaui dengan keperluan pembaca.

\section{II.2 MODEL STRATEGI MANAJEMEN PR}

Kajian sejarah perkembangan public relations memperlihatkan bahwa terdapat empat model dasar public relations sebagaimana yang diidentifikasi oleh James E. Grunig dan Todd Hunt.

Model-model public relations tersebut menggambarkan perbedaan bentuk komunikasi antara organisasi dengan para pemangku kepentingan. Keempat model dasar public relations tersebut adalah model publisitas atau agen pers, model informasi public relations, model persuasif asimetris, dan model simetris dua arah.

\section{Model publisitas atau agen pers}

Model ini menggunakan persuasi dan manipulasi untuk mempengaruhi khalayak untuk memiliki kesan yang sama dengan organisasi dan umumnya para praktisi public relations berperan sebagai jurnalis intern.

\section{Model informasi publik}

Model ini menggunakan press release dan caracara lain yang bersifat teknik komunikasi satu arah untuk mendistribusikan informasi tentang organisasi.

\section{Model asimetris dua arah}


Model ini menggunakan persuasi dan manipulasi untuk mempengaruhi khalayak untuk memiliki kesan yang sama dengan organisasi. Tidak diperlukan penelitian untuk untuk menemukan apa yang dirasakan oleh karyawan atau klien terhadap organisasi.

\section{Model simetris dua arah}

Model ini menggunakan komunikasi untuk bernegosiasi dengan publik, memecahkan masalah, dan untuk mempromosikan pengertian bersama dan rasa hormat antara organisasi dengan karyawan atau klien (Marsh dalam Eadie, 2009 : 717-718). 


\section{BAB III}

\section{PERENCANAAN PR DAN MANAJEMENT KRISIS}

\section{A. Deskripsi Singkat}

Setiap perusahaan atau organisasi tidak dapat dilepaskan dari masalah ataupun konflik yang dapat memicu terjadinya krisis. Sayangnya seringkali pihak manajemen baru menyadari saat konflik telah berubah menjadi krisis yang kronis. Karena itu sangat penting bagi sebuah organisasi untuk melakukan tindakan pencegahan.

Saat krisis semakin bergulir, seringkali informasi yang berkembang menjadi simpang siur dan semakin tak terkendali, bahkan menjadi isu panas yang dapat mempengaruhi opini publik terhadap organisasi. Karena itu organisasi harus segera melakukan manajemen isu sehingga krisis yang ada tidak semakin larut dan berkepanjangan.

Istilah manajemen isu atau "issues management" sendiri merupakan salah satu bagian penting dalam aktivitas public relations. Melihat pada konteks definisi public yang seringkali digunakan, diantaranya menurut Scott M. Cutlip, Allen H. Center, Glen M. Broom, "Public Relations merupakan fungsi manajemen yang membentuk dan memelihara hubungan yang saling menguntungkan antara organisasi dan masyarakat, yang menjadi sandaran keberhasilan atau kegagalannya". Atau pendekatan oleh The Institute of Public Relations yang menyebutkan Public 
Relations sebagai keseluruhan upaya yang dilangsungkan secara terencana dan berkesinambungan dalam rangka menciptakan dan memelihara niat baik dan saling pengertian antara suatu organisasi dengan segenap khalayaknya.

Maka dari kedua konsep singkat tersebut Public relations sendiri Sebagai fungsi manajemen dipandang bertanggung jawab dalam memelihara reputasi positif organisasi atau perusahaan. Dalam konteks manajemen isu dan manajemen krisi PR mengembangkan komunikasi dua arah antara perusahaan dan publik yang dianggap penting untuk menciptakan dan mempertahankan goodwill dan mutual understanding publik terhadap tujuan, kebijakan, dan kegiatan perusahaan. Dalam hal ini, PR menggunakan pendekatan pendekatan komunikasi untuk mengelola berbagai isu yang mengarah pada krisis, dengan berusaha membangun saling pengertian atau mutual understanding dengan publik.

\section{B. Kompetensi Dasar}

- Mahasiswa mampu menyusun tentang perencanaan PR dan dapat menjelaskan Manajement Krisis,memahami pengelolaan emosi dalam komunikasi,

- Mahasiswa dapat memahami proses membangun iklim komunikasi yang supportif dan menghindari iklim komunikasi defensive, serta mengatahui penyelesaian konflik dengan mengelola krisis dengan baik. 


\section{Indikator}

- Mahasiswa mampu menyusun Perencanaan PR dan mengidentifikasi sasaran Target PR

- Mahasiswa mampu menjelaskan definisi krisis.

- Mahasiswa mampu mengidentifikasi jenisi jenis krisis dan sumber sumber krisis

- Mahasiswa mampu mengidentifikasi Anatomi krisis.

- Mahasiswa mampu mengelola Krisis.

\section{PERENCANAAN PR}

Kata Seitel, adalah suatu hal yang esensial tidak hanya untuk mengetahui dimana suatu kampanye khusus yang dikedepankan, tetapi juga untuk memperoleh dukungan top manajemen. Tentu saja, paling sering complain (keluhan /tuntutan) muncul menegenai PR yang membuat kegiatan terburur buru, meerencanakan suatu yang tidak mungkin dan sulit mengukurnya. Pada dasarnya, perencanaan dalam PR harus memberikan gambaran lebih jauh. Dengan perencanaan yang pantas, PR profesional tentunya dapat melakukan dan memperhitungkan tindakan yang mereka ambil.

Sebelum melakukan kegiatan PR, Pejabat PR harus memperhitungkan sasaran dan strategi, perencanaan dan anggaran, serta penelitian dan evaluasi. Lingkungan sekitar yang menjadi cakupan organisasi/ perusahaan harus mencerminkan 
seluruh tujuan tujuan bisnis. Dalam hal ini pula sudah tercermin strategi dan sasaran PR .

Meletakan sasaran, formulasi strategi dan perencanaan adalah esensial (penting) jika fungsi PR dianggap sama derajatnya (setara) dengan komponen lainnya di dalam organisasi / perusahaan tersebut.

Perencanaan memerlukan pemikiran. Perenvanaan suatu program PR jangka pendek untuk mempromosikan pelayanan baru barangkali memerlukan sedikit pemikiran dan waktu dibandingkan dengan perencana kampanye jangka panjang untuk memperoleh dukungan bagi suatu isu kebijakan publik. Meskpun setiap kasus perencanaan PR harus memasukan sasaran yang jelas untuk mencapai tujuan organisasional, strategi untuk mencapai sasaran talktik untuk merealisasikan strategi dan pengukuran untuk menentukan taktik yang mana yang akan diterapkan.

Diantara aspek - aspek yang paling penting bagi PR adalah menetapkan tujuan yang jelas, sasaran dan target bagi penerapan taktik. Kegiatan PR adalah tidak ada artinya jika dirancang untuk mencapai tujuan yang memerlukan tindakan tertentu saja.

Sebagai contoh, Perencanaan PR mendasar yang perlu diperhatikan : 


\section{ENVIRONMENT :}

Kita perlu meningkatkan penjualan produk didalam pasar lokal. Sekarang kita adalah tiga besar dalam pasar, mencapainya dengan cepat mengejar pemasok tempat kedua, tetapi jauh dibelakang market leader ( yang dominan menguasai pasar).

\section{SASARAN BISNIS :}

Tujuan kita adalah ambil bagian dalam membangun pasar untuk produk kita dalam wilayah lokal. Kita mencari untuk mengungguli sebanyak dua Provider (pemasok) dan secara perlahan mencapai posisi nomor satu.

\section{SASARAN PR :}

a) Memperkuat solidnya komitmen perusahaan kita terhadap pelanggan lokal

b) Meyakinkan pelanggan potensial bahwa perusahaan kita menyediakan staf yang ahli dibidangnya, produk bersaing dan responsif terhadap kebutuhan pelanggan

c) Posisis perusahaan kita sebagai pesaing hebat untuk dua market leader (dominasi pasar) 


\section{STRATEGI PR:}

Posisi perusahaan kita merupakan "expert" dalam pasar, melalui survey sponsorship perusahaan dan penelitian langsung pada pengambil keputusan lokal, pemberitaan media dalam bentuk artikel yang berkaitan dengan perusahaan, ahli pidato dipanggung bagi eksekutif perusahaan dan perusahaan menjadi sponsor seminar untuk memperlihatkan keahlian kita.

\section{PROGRAM/TAKTIK PR :}

a) Dicari pemberitaan media dan ditulis sebagai artikel yang membahas prooduk perusahaan pada media lokal

b) Permintaan Penulisan profil untk tulisan feature dan wawancara dengan pejabat perusahaan menjadi feature dan wawancara "excslusive" dengan dominasi publikasi perdagangan

c) Sponsor suatu penelitian triwulan perusahaan lokal. Melalui suvey terhadap pengambilan keputusan, fokus terhadap toppik yang baru perhatian dan pemberian informasi dan komentar dari pandanagn suatu pelanggan

d) Sponsor tempat sebuah seminar tiap tahunnya utnuk menunjukan penggunaan produk perusahaan diwilayah lokal 
e) Menurunkan wakil pembicara perusahaan, dimana pembicara perusahaan itu berbicara diantara kelompok kelompok terkemukan diwilayah itu.

\section{III.1. PENGELOLAAN TARGET PR}

Tujuan suatu organisasi harus pula membatasi apa tujuan PR - nya yang ingin dicapai dan hanya tujuan tujuan yangg baik yang dapat dicapai. Sasaran / target dan strategi PR yang berada didalamnya, sepatutnya masuk dalam area bisini lainnya, harus beroientasi hasil. Public Relations profesional dalam pengelolaan sasaran/target yang hendak dicapainya melakukan pengadopsian tehnik-tehnik Management of Objective (MBO) dan Management by Objective of Result (MOR) untuk membantu kualitas nilai Public Relations dalam suatu organisasi.

MBO dapat memberikan profesional Public Relation dengan sumber umpan yang sangat kuat. MBO dan MOR berhubungan dengan hasil-hasil Public Relations untuk penentuan target awal manajemen. Adapun poin-poin dalam MBO menurut Sholeh Soemirat dan Elvinaro Ardianto (2003:98) adalah sebagai berikut :

1. Spesifikasi tujuan-tujuan organisasi dengan mencapai target penampilan organisasi.

2. Konferensi antara superior dan subordinate (bawahan) untuk menyepakati terhadap pencapaian tujuan. 
3. Kesepakatan antara atasan dan bawahan pada target yang konsisten dengan tujuan-tujuan organisasi.

4. Pengkajian secara periodik oleh atasan dan bawahan untuk menilai kemajuan pencapaian tujuan.

Adapun kunci penggunaan MBO secara efektif dalam tugas Public Relations dapat di pecah ke dalam tujuan tahap secara kritis :

1. Memiliki batasan dan misi kerja.

2. Menetapkan kunci areal keberhasilan (hasil) dalam jangka waktu tertentu, berupaya dan berkepribadian.

3. dentifikasi fakto-faktor menentukan tindakan pada target yang telah ditentukan.

4. Meletakan target/menetapkan hasil yang akan dicapai.

5. Persiapan perencanaan secara taktis untuk mencapai target khusus, termasuk :Pemrograman untuk memantapkan suatu rangkaian tindakan untuk mengikutinya.

Penjadwalan waktu yang dibutuhkan bagi setiap tahapan penganggaran untuk menugaskan sumber daya yang dperlukan bagi pencapaian tujuan Pemantapan pertanggung jawaban secara individu untuk pencapaian target/sasaran.Pengkajian dan 
rekonsiliasi (perdamaian) melalui suatu prosedur testing untuk membawa kemajuan.

6. Pemantapan keputusan dan peraturan untuk mengikutinya.

7. Pemantapan prosedur untuk menangani pekerjaan

\section{III.3. MANAJEMENT KRISIS}

\section{Definisi Krisis :}

Setiap organisasi dimungkinkan mengalami sebuah krisis dalam operasional sehari hari. Krisis tersebut harus dimanage dengan baik jika organisasi berkeinginan untuk dapat bertahan dalam pertarungan yang ketat di era global saat ini. Setiap krisis mempunyai potensi memengaruhi citra organisasi, khususnya jika krisis tersebut berkembang menjadi bencana yang mempunyai dampak luas bagi masyarakat. Dalam hal ini , reputasi organisasi dapat menurun drastis dan membuat organisasi menjadi objek kritikan dan cemoohan masyarakat. Akibatnya organisasi tersebut akan mengalami kerugian besar, seperti menurunnya tingkat penjualan, modal, keuntungan, nilai saham dan rasa percaya diri. Krisis adalah masa gawat atau saat genting, dimana situasi tersebut dapat merupakan titik baik atau sebaliknya. Oleh karena itu masa krisis adalah momen momen tertentu. Apabila krisi ditangani dengan baik dan tepat waktu, momen mneegarah pada situasi membaik dan sebaliknya apabila tidak segera 
ditangani krisis mengarah kepada situasi memburuk bahkan dapat berakibat fatal (dikutip dai buku diktat Interstudi School Of PR 1993). Menurut Duke \& Masland (2002) dan Kouzmin (2008) mereka menekankan krisis sebagai situasi yang menyebabkan kerusakan kerusakan fisik dan non fisik seperti peristiwa yang membahayakan jiwa manusia(meninggal atau luka luka) dan merusak sistem organisasi dan lingkungan secara keseluruhan , khususnya bagi korban. Menurut Philip Lesly dalam bukunya Everything You Wanted to Know About Public relations, sumber krisis antara lain :

1) Bencana seperti kebakaran, gempa bumi, akan berpengaruh terhadap orang orang dalam dan publik luar perusahaan seperti : pelanggan, agen, investor publik, komunitas suatu pabrik/ perusahaan

2) Kondisi darurat yang datang secara tiba tiba atau suatu perkembangan kondisi darurat ini seperti sabotase produk perusahaan atau produk yang mnegandung racun.

3) Penanaman bom dapat menimbulkan kepanikan dan kerusakan atau pemogokan karyawan perusahaan.

4) Rumor yang jelek tentang perusahaan atau produk

5) Adanya letupan seperti boikot dari berbagai aktivis (semacam LSM), permintaan pemerintah menarik produk, penculikan seorang eksekutif perusahaan. 


\section{KARAKTERISTIK KRISIS}

Karakteristik Krisis antara lain :

1. Peristiwa yang spesifik (specifik event)

Penyebab krisis dapat diketahui . Suatu organisasi dapat mengalami satu macam krisis, seperti demonstrasi karyawan atau krisis yang menerpa produknya. Tetapi, dimungkinkan pada saat yang sama, organisasi tersebut mengalami diua macam atau lebih krisis.

2. Krisi bersifat telah diharapkan dan dapat terjadi setiap saat.

Krisis cenderung menbagncam kehidupan organisasi atau publiknya, sehingga tidak seorangpun dalam organisasi ayng mengharapkan krisis terjadi. Krisis terjadi sebagian bagian dari aktivitas organisasi. Krisis tidak diharapkan karena dapat menghasilkan kerusakan, ancaman, menimbulkan korban jiwa dan dapat mengubah sistem sosial budaya. Krisis bersifat tidak terduga dengan baik akan memicu krisis, tetapi organisasi tidak dapat memastikan kapan krisis tersebut terjadi ( commbs,2007b:136).

3. Krisis menyebabkan ketidakpastiN Informasi.

Pada awal krisis, biasanya muncul rumor. Rumor adalah informasi yang tidak jelas darimana asalnya, sipaa yang membawanya dan kebenarannya tidak dadpat 
dipertanggungjawabakan. Rumor terjadi karena setiap orang mempunyai kesempatan untuk mengira ngira atau membuat analisis sendiri tentang apa yang terjadi. Untuk mengatasinya, Public relations mesti proaktif ddan menyediakana saluran komunikasi yang dapat menyebarkan informasi yang benar kepada publik. Jika tidak, maka rumor akan menyebar keluar organisasi. Menurut G.Haririson(2005) aktivitas publik relations dalama menyediakan pesan pesan yang relevan dengan situasi krisis ddan membuka saluran komuniaksi yang terbuka, disebut sebagai komunikasi krisis ( crisis communication).

\section{Menimbulkan Kepanikan.}

Kepanikan bisa munul akibat ketidakpastian dan kekurangan informasi. Situasi ini memunculkan rumor yang tidak jelas sumber dan kebenarannya.

5. Menimbulkan dampak bagi operasional organisasi.

Krisis menimbulkan dampak bagi operasional organisasi. Dampak ini dapat bersifat negatif, seperti penurunan profit, penurunan kepercayaan publik, pemerintah dan publik tiada henti hentinya memperhatikan perhatian besar atau bahkan mengivestigasi organisasi, mengancam reputasi dan nama organisasi, perubahan yang bersifat tidak produktif (misalnya kehilangan 
modal, pengunduran diri karyawan dan pemusatan hubungan kerja masal dan hilangnya waktu untuk mengatasi konflik). Krisis juga memunculkan dampak yang tidak terduga duga seperti masalah masalah yang selama ini terpendam tiba tiba muncul ke permukaaan dan munculnya kompetitor baru. Tetapi, krisis juga berpotensi menjadi awal yang baik bagi organisasi seperti munculnya pahlawan baru atau seseorang yang akhirnya menjadio pemimpin baru yang membawa organisasi keluar dari krisis, munculnya strategi strategi baru ( misalnya organisasi mulai berpikir perlunya strategi komunikasi baru atau sistem "early warrning" yang baru), munculnya kebijakan kebijakan baru ( misalnya organsisasi membuat aturan baru untuk mencegah krisis tejadi lagi ) dan peluang memunculkan perubahan yang lebih baik. Agar krisis dapat menjaadi titik balik menuju yang lebih baik maka organisasi dituntut merencanakan dan melaksanakan strategi krisis dengan baik selaam dan sesudah krisis (post crisis communication).

\section{Berpotensi menimbulkan konflik}

Konfilik terjadi karena adanya ketidak sesualn antara harapan dan kenyataan. Konflik bisa terjadi diinternal organisasi atau juga antara organisasi dengan publik 
eksternal ( konflik eksternal). Krisis memunculkan pro kontra dan debat publik akibat pemebritaan media massa dan perhatian publik yang terus menerus.

\section{SUMBER DAN JENIS KRISIS}

G. Haririson (2005) dan White \& Mazur (1995) menyimpulkan bahwa krisis secara umum dapat disebabkan oleh dua sumber ayitu dari ddalam dan dari luar organisasi. Sumber krisis dari dalam organisasi antara lain : Manusia manajemen dan teknologi, sumber dari luar yaitu : peraturan peraturan pemerintah, bencana alam dan kerusakan yang dilakukan oleh orang lain. Krisis dapat terjadi melalui beberapa peristiwa, sesuai dengan kejadiannya. Jenis krisis dapat digolongkan antara lain :

1. Kecelakaan industri

2. Masalah lingkungan

3. Masalah perburuhan

4. Masalah produk

5. Masalah dengan investor, desas desus, isu

6. Peraturan pemerintah

7. Terorisme

Biasanya krisis timbul apabila kejahteraan terganggu, telah terjadi pergeseran kecenderungan perhatian masyarakat dari masalah poltik ke arah ekonomi (kesejahteraan) dan perbaikan kualitas hidup. Masalah masalah yang mengganggu kejahteraan akan 
menjadi masalah yang sangat sensitif yang akhirnya timbul ke permukaan menjadi krisis. Tempat terjadinya krisis dapat terjadi dalam bentuk konkrit dan bentuk abstrak. Misalnya : masalah perburuhan, berita di surat kabar, peraturan pemerintah dan terorisme. Sesuai dengan lokasinya, krisis dapat terjadi di dalam dan di luar perusahaan. Misalnya kecelakaan industri di sebuah pabrik, kebakaran kilang minyak lepas pantai.

Berdasarkan sumber sumber krisis, krisis dapat dikelompokan kedalam beberapa jenis yaitu :

\section{Krisis Teknologi.}

Krisis yang disebabkan oleh kesalahan penggunaan teknologi tertentu dalam operasional. Contoh : kasus ledakan nuklir, kesalahan pengebiran yang diduga menyebabkan lumpur meluap di Sidoarjo, krisis lumpur Lapindo 2006 yang menewaskan 14 orang dan membuat 60 ribu orang kehilangan rumah dan desanya, bocornya kilang kimia di Boqal India yang menewaskan ribuan orang pada april 2012 peluncuran roket milik korea Utara menimbulkan krisis antara Korea utara dan beberapa negara tetangga adlaah krisis yang disebabkan oleh penggunaan teknologi roket yang dituduh oleh negara negara barat membawa nuklir yang dilarang PBB ( meski tidak terbukti). 


\section{Krisis Konfrontasi.}

Relasi yang buruk antara organisasi dan publik dapat merangsang terjadinya konfrontasi, yang akhirnya memicu krisis. Ini terjadi bila publik mengekspresikan kemarahannya (publik outrage), karena ketidakpuasannya terhadap operasi sehari hari organisasi. Demonstarasi besar besarna menentang kenaikan bahan bakar minyak di tahun 2012 adalah krisis akibat tindakan pemerintah yang akan menaikan BBM.

3. Krisis Malevolence.

Terjadi bila seseorang atau kelompok mempunyai keinginan untuk menjatuhkan atau membahayakan organisasi, seperti sabotase atau teroris yang mengebom area bisnis dan mengganggu aktivitas organaisasi. Boim Bali tahun 20002 yang menewaskan 202 orang adalah contoh krisis yang diakibatkan ulah manusia ayng merusak.

\section{Krisis Manajemen.}

Terajadi karena kelompok manajemen gagl melaksanakan tanggung jawabnya. Sebagai contoh : korupsi yang dilakukan manajemen seorang bank yang kalah dalam permainan valas, pergantian manajemen, take over (akuisisi). Kasus kasus korupsi wisma atlet dan proses pemilihan ketua partai yang melibatkan para 
petinggi parti Demokrat pada 2011 - 2012 adlah krisis yang bersumber pada perilaku manajemen partai.

5. Krisis Bencana Alam.

Krisis yang disebabkan oleh bencana alam yang memengaruhi aktivitas organisasi seperti banjir, tanah longsor, dan gempa bumi. Contoh : Tsunami di Aceh, 26 desember 2004 yang menewaskan216 ribu orang dan kerusakan harta benda ; Meletusnya gunung Merapi di Jawa Tengah yang membuat 900 ribu orang kehilangan pekerjaan.

6. Krisis Produk.

Krisis yang elibatkan kesalahan produk, seperti sebuah produk yang mengandung zat berbahaya. Keracunan produk Tyanol milik Johnson and Johnson di tahun 1982.

Mereka yang harus duduk dalam tim krisis adalah orang orang yang dapat mewakili kepentingannya antara lain :

1. Hukum, la harus diwakili karena sangat banyak melibatkan kpeentingan hukum.

2. Pimpinan tertinggi, mereka harus mengambil keputusan secara cepat.

3. Pejabat Public Relations, karena PR harus mampu menggalang dan mengawasi liputan semasa krisis dan sesudah krisis untuk mengembalikan citra perusahaan. 
4. Personal industri Relations, mereka diperlukan karena setiap krisis akan melibatkan tenaga kerja.

5. Employee Communications, sering dadlam krisis tindakan yang diambil hanya pengamanan siaran kepada masyarakat, siaran kepada karyawan jangan dilupakan karena dapat menjadi bumerang (memukul balik).

6. Petugas Keamanan Pabrik, merekalah yang berhubungan dengan petugas keamanan untuk menjaga kpeentingan penyelesaian krisis.

7. Kegiaatan Teknis, sangat diperlukan jika menyangkut karena adanya benda benda beracun dan berbahaya.

8. Kesehatan/medis, diperlukan karena mereka harus membantu korban korban yang berjatuhan.

9. Juru Potret, diperlukan pengambilan gambar gambar baik untuk pelajaran menghadapi krisis maupun untuk kepentingan hukum dan pembelaan.

10. Kontak dengan Media, Penunjukan seorang juru bicara, agar seluruh keterangan hanya datang dari satu sumber untuk mencegah simpang siurnya keterangan.

Resiko yang timbul sebagai akibat dari krisi adalah :

1) Intesitas masalah menjadi meningkat

2) Dibawah sorotan publik

3) Dibawah tekanan pemerintah 
4) Operasional normal perusahaan menjadi terganggu

5) Nama baik, produk dan citra perusahaan terancam

\section{III.2. ANATOMI KRISIS}

menurut Fink dibagi menjadi 4 (empat) tahap, yaitu tahap prodromal, tahap akut, tahap kronis, dan tahap resolusi. Berikut di bawah ini penjelasan dari keempat tahap tersebut:

\section{A). Tahap Prodromal}

Tahap prodromal adalah tahap ketika konflik mulai muncul menjadi krisis. Tahap ini biasa disebut dengan warning stage yang merupakan peringatan terhadap bahaya yang harus segera diatasi. Namun, pada tahap prodromal, krisis belum terlihat jelas meskipun terdapat isu-isu yang menyebar. Jarang adanya instansi yang menyadari krisis pada tahap prodromal tetapi ada pula yang menyadarinya hingga diketahui oleh pihak internal instansi kemudian berhasil ditangani. (Handayani \& Anom, 2010).

\section{B). Tahap Akut}

Tahap akut adalah tahap ketika krisis sudah terlihat dan disadari oleh pihak internal maupun eksternal instansi. Isu pada tahap ini pun telah banyak beredar di berbagai daerah dan juga di media. Semakin 
kompleks isu yang beredar, maka semakin besar pula intensitas krisis pada tahap akut. (Handayani \& Anom, 2010).

\section{C). Tahap Kronis}

Pada tahap kronis, krisis semakin terlihat dan semakin terpublikasi oleh berbagai media, bahkan korban pun semakin banyak dan krisis rentan untuk dikendalikan. Krisis di tahap ini membutuhkan pihak lain yang handal untuk pemulihan kasus hingga krisis berubah menjadi keadaan yang lebih baik. (Handayani \& Anom, 2010).

\section{D). Tahap Resolusi}

Tahap resolusi merupakan tahap pemulihan yang dilakukan oleh instansi untuk mengatasi kasus dan memperbaiki hubungan instansi di mata publik. Pada tahap ini, instansi harus terus berhati-hati karena tidak menutup kemungkinan untuk krisis dapat muncul kembali. Apabila instansi tidak dapat memulihkan krisis dengan tuntas, maka krisis akan kembali ke tahap prodromal yang kemudian harus diatasi kembali dengan baik. (Handayani \& Anom, 2010). 


\section{III.3 BAGAIMANA MENGATASI KRISIS (MENGELOLA KRISIS)}

Strategi yang digunakan praktisi Public Relations dalam merespon krisis menunjukkan bagaimana sikap yang diambil oleh organisasi pada saat krisis sedang berlangsung, sehingga posisi Public Relations dalam manajemen krisis bisa diibaratkan sebagai ujung tombak. Agar fungsi strategis ini dapat dijalankan dengan baik, posisi bidang Public Relations harus langsung dibawah pimpinan puncak. Menurut Cultip \& Center, dalam bukunya Effective Public Speaking mengatakan bahwa idealnya bagian Humas dimasukkan dalam staf inti, langsung berada dibawah pimpinan (decision making) atau top

managers, agar lebih mampu dalam menjalankan tugasnya. Dengan posisi tersebut Praktisi PR/Humas dapat mengetahui secara langsung latar belakang dari suatu keputusan yang diambil oleh pimpinan lembaga, sehingga langsung mendapat bahan informasi untuk disampaikan kepada public yang bersangkutan. Dengan demikian insan public relations mempunyai kewenangan yang memungkinkan fungsi tersebut dapat dijalankan secara efektif. Dalam kaitannya dengan penanganan krisis, public relations memiliki tanggung jawab besar, mengingat dampak negatif dan kerugian besar, bahkan citra organisasi atau perusahaan akan terancam dengan adanya krisis. 
Praktisi Public Relations sebagai yang ikut berkepentingan menangani krisis, dapat menggunakan strategi 3P, sebagai berikut (Ruslan, 1994 : 104-106) :

\section{Strategi Pencegahan}

Adalah tindakan preventif melalui antisipasi terhadap situasi krisis. Dalam hal ini Public Relations dituntut memiliki kepekaan terhadap gejala-gejala yang timbul diawal sebelum krisis terjadi, dituntut untuk memiliki kemampuan berpikir strategis dalam menganalisa dan sekaligus memposisikan masalah krisis agar nantinya dapat dicegah secara dini.

\section{Strategi Persiapan}

Bila krisis tidak dapat dicegah sejak dini, maka diperlukan langkah-langkah sebagai berikut :

1. Membentuk tim krisis harus selalu mengadakan komunikasi agar suasana krisis dapat terpantau.

2. Tim krisis harus dapat informasi yang jelas dan akurat tentang perkembangan krisis, sehingga informasi yang diberikan kepada pers tidak menyimpang dengan situasi yang sebenarnya.

\section{Strategi Penanggulangan}

Yaitu apabila strategi pencegahan dan persiapan tidak sempat dilaksanakan, langkah terakhir yang diambil strategi penaggulangan yaitu masa kuratif. Dalam strategi penanggulangan terdapat langkah langkah yang harus diambil 
sesuai dengan situasi dan kondisi. Penanggulangan krisis harus segera diatasi, sebab hal tersebut dilakukan agar krisis tidak menyebar dan berkembang ke sektor lain. Selain itu agar operasional organisasi tidak terganggu dan berjalan efektif. Dengan mengevaluasi krisis yang terjadi bertujuan untuk melihat sejauh mana perkembangan krisis di masyarakat, serta untuk mengetahui dimana kelemahan dan kelebihan dalam pelaksanaan program manajemen krisis. Soemirat dan Ardianto menawarkan strategi penganggulangan krisis sebagai tindakan kuratif. Tindakan ini dilakukan jika krisis telah benar-benar terjadi dan tidak sempat atau dapat mencegahnya. Dalam strategi penanggulangan terdapat langkah langkah yang harus diambil sesuai dengan kondisi kritis :

1) Kondisi Krisis akut, pengamanan yang harus dilakukan dadlam kondisi ini melalui tahap tahap:

a) Mengidentifikasi krisis,mencari penyebab timbulnya krisis. Sebab tanpa mengetahui penyebabnya, penanggulangan krisis menjadi sulit. Sebaliknya faktor penyebab diketahui, maka perusahaan dapat memastikan apakah krisis dapat ditanggulangi atau tiddak :

b) Mengisolasi krisis, agar krisis ini sanagt ditangani sebaik mungkin, krisis perlu diisolasi, agar operasional perusahaan tidak terganggu, agar 
efektivitas penanggulangan dapat ditingkatkan. Tim khusus dibebaskan dari kegiatan rutinnya, bisa bekerja sama dengan konsultan Public Relations. Tim Khusus menunjuk juru bicara untuk menghadapi publik pers agar kesimpangsiuran berita dapat dicegah

c) Mengendalikan krisis, agar krisi tidak meluas, krisis harus dikendalikan. Setalah krisis berhasil diidentifikasi, penanggulangan dapat dilaksanakan. Itulah penanggulangan krisis berhasil dikendalikan. Dalam hal ini keputusan tepat dan baik harus diambil.

2) Kondsi kesembuhan, Kondisi ini merupakan saat diaman perusahaan mengintropeksi mengapa krisis terjadi. Bagi perusahaan tidak dapat tercapai. Hal ini akan menjadi masa kegoncangan bahlkan kebangkrutan perusahaan. Bagi perusahaan yang berhasil menanggulangi krisis dengan baik berarti kondisi kesehatan dapat dicapai. Sehingga masa ini adalah masa yang menenangkan ayng mengarah kepada pemulihan (kesembuhan).

\section{PERANAN PUBLIC RELATIONS DALAM MASA KRISIS}

Public realtions mempunyai peranan penting dalam menangani masa krisis, mengingat masa krisis dapat berdampak 
negatif terhadap citra perusahaan, sehingga dapat dikatakan Public relations merupakan fungsi manajemen yang strategis.

Agar fungsi startegis ini dpat dijalankan dengan baik, posisi divisi/bidang Public reklations harus langsung dibawah pimpinan puncak dengan demikian insan public relations mempunyai kewenangan yang memungkinkan fungsi tersebut dapat dijalankan secara efektif.

Dalam menjalankan peran tesrebut insan public relations harus membuat langkah langkah startegisnya :

1. Press Relations ( hubungan Pers)

2. Goverment relations(hubungan Pemerintah)

3. Opinion Leader relations (hubungan dengan pemuka pendapat)

4. Trade relations ( hubungan perdagangan).

Hal hal yang dilakukan dalam mengatasi krisis adalah :

1. Fact Finding

Mencari dan mengumpulkan data, termasuk data penyebab

2. Membentuk pusat infomrasi

3. Pilih juru bicara

Pilih juru bicara yang mampu dan berpengalaman,. Pastikan bahwa juru bicara mendapatkan semua data dan informasi sumber data yang benar. 
4. Berikan keterangan yang cukup,jelas dan benar kepada pers agar mereka tidak mencari ke sumber yang tidak sesuai.

5. Membuat dokumentasi kejadian tersebut berupa foto,tape atau video sebagai data.

6. Memperbaruhi data data pers dari waktu ke waktu

7. Memberitahukan operator bahwa tidak ada seorang pun yang memberikan keterangan selain juru bicara

8. Permintaan Pers untuk kepentingan Informasi mereka harus dipenuhi secepatnya.

Hal hal yang TIDAK BOLEH dilakukan dalam mengatasi Krisis :

1. Jangan berkata "Non comment" kepada Pers, karena hal itu akan memancing spekulasi atau praduga.

2. Jangan membesar besarkan keadaan.

3. Jangan menyatakan "OFF the record"

4. Jangan menyimpang dari kebijakan perusahaan. 


\section{BAB IV}

\section{MEMANFAATKAN BUDAYA PERUSAHAAN}

\section{A. Deskripsi Singkat}

Budaya perusahaan atau budaya korporat berkaitan erat dengan strategi. Strategi ini berkaitan erat dengan strategi manajemen perusahaan . strategi ini dirumuskan oleh para pimpinan puncak dengan mengaitkan kedudukan perusahaan dalam lingkungannya. Dengan membentuk budaya yang pas diantara orang orang di dalam perusahaan, perusahaan akan mendapat lebih mudah bersaing dan meraih keberhasilan. Jika lingkungan sangat kompleks, misalnya, perusahaan perlu didesain fleksibel dan responsif terhadap perubahan lingkungan. Kultur yang dibangun selayaknya adalah kultur adaptasi.

Karena pekerjaan PR adalah pekerjaan komunikasi , kaitannya dengan budaya perusahaan sangat erat. Seorang praktisi PR memang sering diminta pendapatnya tentang budaya perusahaan oleh pimpinan puncak. Namun tugas menyusun/ merumuskan budaya perusahaan bukanlah tugas praktisi PR seorang diri. Barangkali yang lebih tepat dapat dikatakan, seorang praktisi PR membantu pimpinan dalam merumuskan budaya perusahaan. Dengan bekal rumusan itu praktisi PR dapat menyusun program komunikasi ke luar maupun ke dalam, 
misalnya merumuskan identitas perusahaan (logo), alat-alat komunikasi ( media) dan sebagainya.

\section{B. Kompetensi Dasar}

Mahasiswa mampu merumuskan dan mengembangkan organisasi / perusahaan melalui budaya perusahaan

\section{Indikator}

- Mahasiswa mampu mendefinisikan budaya perusahaan.

- Mahasiswa mampu mengidentifikasi potensi budaya perusahaan.

- Mahasiswa mampu mengidentifikasi manfaat budaya perusahaan.

- Mahasiswa mampu mengenal dan mengelola budaya perusahaan.

- Mahasiswa mampu mengetahui strategi manajement terhadap budaya perusahaan.

\section{IV.1 PENGERTIAN BUDAYA PERUSAHAAN}

Budaya adalah satu set nilai, penuntun kepercayaan akan suatu hal, pengertian dan cara berpikir yang dipertemukan oleh para anggota organisasi dan diterima oleh anggota baru seutuhnya. Secara pragmatus, budaya organisasi (perusahaan) dapat diartikan sebagaia: 'Norma-norma perilaku, sosial, dan moral yang mendasari setiap tindakan dalam organisasi dan 
dibentuk oleh kepercayaan, sikap, dan prioritas para anggota." (Tuner, 1992).

Tujuan keberadaan budaya suatu organisai adalah melengkapi anggota dengan rasa (identitas) organisasi dan menimbulkan komitmen terhadap nilai-nilai yang dianut organisasi.

Budaya korporat terdiri atas dua lapis. Lapisan pertama adalah lapisan yang umumnya mudah dilihat dan sering dianggap mewakili budaya perusahaan secara menyeluruh, dan biasa disebut Visible Artifacts. Seperti misalnya cara orang berpakaian, berdandan serta simbol-simbol. la hadir mewakili nilai-nilai yang lebih dalam dari para anggota. Lapisan kedua yang lebih dalam itulah yang sesungguhnya disebut budaya. Ini terdiri atas nilai-nilai pokok, filosofi, asumsi, kepercayaan, sejarah korporat, dan proses berpikir dalam organisasi.

\section{IV.2 BUDAYA PERUSAHAAN DAN STRATEGI MANAJEMEN}

Strategi adalah hal penting yang harus durencanakan dan diputuskan dalam sebuah perusahaan, bahkan persoalan strategi ini menjadi bagian yang krusial di dalam sebuah perusahaan. Strategi merupakan jantung dari konsep manajemen stratejik. Strategi adalah langkah paling mendasar bagi perusahaan di dalam mencapai tujuan perusahaan. Strategi menunjukkan bagaimana kemampuan perusahaan dalam menyelaraskan sumberdayanya 
dengan tuntutan perubahan lingkungan perusahaan. Dengan Strategi, perusahaan akan berjuang untuk mendayagunakan berbagai pilihan yang ada untuk dapat menghadapi ancamanancaman yang ada, dan mendayagunakan berbagai keunggulan perusahaan untuk meminimalkan kelemahan-kelemahan perusahaan dalam suatu kompetisi yang baik. Pada perkembangan dewasa ini, strategi lebih bersifat dinamis dan strategi dipandang sebagai proses yang berkelanjutan, oleh sebab itu perusahaan berupaya untuk dapat membentuk strateginya.

Terdapat beberapa komponen dasar dimana perusahaan memerlukan strategi, yaitu:

a. Kegiatan-kegiatan bisnis yang merupakan kegiatan utama perusahaan

b. Keunggulan bersaing dari perusahaan yang akan dicapai perusahaan

c. Alokasi pendayagunaan sumberdaya perusahaan untuk mencapai tujuan perusahaan. Dengan strategi, kegiatan utama perusahaan, produk atau jasa yang ditawarkan, dan rencana perusahaan dapat ditetapkan dan selanjutnya perusahaan akan lebih mudah menentukan cara yang spesifik untuk memunculkan keunggulan bersaingnya. Dalam menetapkan strategi bersaingnya, maka perusahaan dihadapkan pada berbagai pilihan, diantaranya : pilihan pertama merujuk pada besarnya pasar yang akan dilayani atau difokuskan pada 
segmen pasar tertentu, pilihan kedua merujuk pada cara perusahaan untuk mencapai keunggulannya dengan menjadi pemimpin pasar atau diferensiasi. Setelah pilihan-pilihan tersebut ditentukan, akhirnya perusahaan dapat menetapkan pendayagunaan sumber daya yang ada (material, keuangan, SDM) dalam suatu implementasi kegiatan-kegiatan perusahaan yang strategis. Manajemen strategi adalah suatu proses dalam memformulasikan dan mengimplementasikan strategi yang terdiri dari tiga tahap kegiatan utama, yaitu : kegiatan menganalisis, pemilihan strategi, implementasi strategi. Kegiatan analisis meliputi kegiatan dalam menganalisis misi dan tujuan perusahaan, analisis factor-faktor lingkungan eksternal dan analisis faktor-faktor lingkungan internal perusahaan (kemampuan dan sumberdaya yang dimiliki perusahaan). Pemilihan strategi meliputi kegiatan menyusun pilihan strategi, evaluasi dan pemilihan strategi. Pemilihan strategi ini akan berupa pemilihan atas berbagai alternative tanggapan perusahaan terhadap situasi lingkungan perusahaan yang perlu diselaraskan dengan kemampuan dan sumberdaya yang dimiliki perusahaan. Implementasi strategi meliputi kegiatan pelaksanaan strategi melalui perencanaan atas berbagai kegiatan dan pengalokasian sumberdaya perusahaan. Setelah ketiga tahap utama tersebut dilakukan, penting bagi perusahaan untuk melakukan penyesuaian-penyesuaian 
kembali terhadap strategi sehingga strategi perusahaan benarbenar dapat diaplikasikan dan memberikan implikasi pada terjadinya perubahan kinerja dalam perusahaan. Pada tahap akhir ini, manajemen perubahan mungkin perlu diterapkan dan menjadi bagian dari penerapan strategi dalam perusahaan. Budaya perusahaan dapat diartikan sebagai suatu sistem atas asumsi budaya, nila inilai yang dipegang, norma dan sikap yang ditunjukkan dalam bentuk symbol-simbol dimana semua orang dalam perusahaan mengembangkannya dan menerimanya. Budaya perusahaan diharapkan dapat mereka yakini yang dapat membantu mereka dalam memaknai lingkungan perusahaan tempat mereka berkarya dan bagaimana setiap orang dalam perusahaan itu berperilaku di dalam perusahaan tersebut. Berdasarkan pada pengertian ini, dapatlah kita simpulkan bahwa budaya perusahaan akan terbentuk dari struktur kognitif bersama, berupa asumsi, nilai, norma yang dinyatakan dalam bentuk sikap dan perilaku. Budaya perusahaan memberikan konsekuensi kolektif pada interaksi sosial dari setiap orang di dalam perusahaan. Kosekuensi kolektif ini akan berdampak pula pada pemecahan masalah perusahaan dan dalam perusahaan menyesuaikan diri dengan lingkungan eksternalnya. Dengan budaya perusahaan, pemecahan masalah dapat dilakukan bersama dengan lebih sistematis, dan hasilnya adalah untuk semuanya yang sudah 
terlibat sehingga kemudian akan terbentuklah struktur kognitif bersama yang dibagikan pada seluruh karyawan yang ada di perusahaan dan juga para manajer.

Dengan tertanamnya dan terbangunnya struktur kognitif bersama tersebut, maka para karyawan sudah memiliki arahan dan pedoman yang jelas di dalam menginterpretasikan lingkungan disekitar mereka dan bagaimana seharusnya mereka bersikap dan berperilaku di dalam perusahaan tersebut. Budaya perusahaan sangat membantu para karyawan dan para manajer dalam memahami dan mengartikan konsep, sesuatu hal dan kejadiankejadian yang terjadi baik di dalam perusahaan maupun diluar perusahaan. Dengan demikian mereka akan dapat lebih mudah dalam membuat keputusan, melakukan suatu tindakan, dan juga berinteraksi dengan lingkungannya. Suatu studi yang dilakukan oleh Profesor Daniel R.Denison, menunjukan bahawa ada empat jenis budaya yang dapat dikembangkan perusahaan sehubungan dengan strategi dan keadaan lingkungan :

\section{Budaya Adaptasi}

Budaya adaptasi ditandai oleh lingkungan yang tidak stabil dengan strategi terfokus pada kegiatan ekstern. Pada Budaya adaptasi ini orang orang di dalam perusahaan diarahkan agar dapat mendukung kapasitas organisasi untuk 
mengungkap tanda tanda dan menafsirkan tindakan terhadap perubahan lingkungan ke dalam prilaku baru. Perusahaan yang menganut budaya ini memerlukan respon yang segera untuk menyesuaikan diri dengan perubahan lingkungan . Umumnya budaya ini dianut perusahaan eletronik, pemasaran ,Fashion goods dan produsen kosmetik.

\section{Budaya Misi}

Budaya ini ditandai oleh keadaan lingkungan yang relatif stabil. Dalam keadaan lingkungan yang stabil perusahaan mulai memperhatikan orang orang diluar perusahaan. Tujuannya adalah untuk menyebarkan visi perusahaan kepada khalayak. Visi tersebut memberi arti bagi para anggota dengan mendefinisikan secara jelas perannya dalam perusahaan. Orang orang didalam perusahaan percaya bahwa misi perusahaan adalah untuk melayani orang.

\section{Budaya Partisipastif}

Budaya ini menfokuskan perhatiannya pada keterlibatan seluruh orang dalam perusahaan terhadap perubahan lingkungan yang cepat (unstable), perusahaan membangkitkan inisiatif 
para karyawan agar terlibat dalam kebersamaan melalui rasa tanggung jawab dan rasa memiliki dan komitmen yang tinggi terhadap perusahaan. Umumnya perusahaan mengijinkan karyawan bekerja tanpa jamn kerja rutin sehingga karyawan bisa mengatur sendiri jadwalnya dan bersedia bekerja hingga larut malam. Rasa kepemilikan dikembangkan melalui profit sharing atau gain sharingi (Kepemilikan saham secara berkelompok seperti dalam koperasi ).

\section{Budaya Konsisten}

Budaya ini dikembangkan dalam keadaan lingkungan yang stabil. Dalam keadaan itu, perusahaan menfokuskan strateginya ke arah intern perusahaan. Simbol, kepahlawanan, dan protokoler yang didesain oleh praktisi PR dimaksudkan utnuk mendukung kerja sama, tradisi dan mengiktui kebijakan perusahaan mencapai sasaran tertentu. Di dalam perusahaan ini, keterlibatan /partisipasi individu tidak terlalu menonjol tetapi diimbangi dengan niat baik untuk menyesuaikan diri dan kerja sama antara anggota. Keberhasilan perusahaan ditimbulkan 
oleh hubungan antara bagian bagian dan manusiannya yang saling berpadu dan efesien.

\section{IV.3 BAGAIMANA PR MEMANFAATKAN BUDAYA PERUSAHAAN}

Budaya korporat dapat ditumbuhkan dengan menata elemen-elemennya. Dalam melakukan transformasi nilai-nilai, elemen-elemen ini harus ditata kembali, diperiksa seberapa jauh manfaat dan konsisitensinya untuk menimbulkan penafsiran yang sama di antara seluruh pelaku dalam organisasi. Elemen-elemen tersebut yakni:

\section{Sejarah Korporat}

Setiap organisasi punya sejarah yang tidak dapat dihapus begitu saja karena sejarah adalah sumber kekuatan sebuah korporasi (corporate roots). Namun tidak menutup kemungkinan suatu korporasi mengabaikan asal-usulnya, dimana mereka berada dan ke mana akan dibawa.

\section{Nilai-nilai Dasar dan Keyakinan}

Nilai-nilai dasar (values) dan keyakinan (beliefs) adalah fondasi sebuah identitas korporat. Nilai-niai adalah sesuatu yang memaknai jadi diri seseorang sebagai anggota korporasi (What we stand for) dalam keadaan seperti apapun. Sedangkan keyakinan adalah sesuatu yang dipercayai bersama 
(a shared vision). Masalahnya, nilai-nilai dan keyakinan yang sering dituangkan ke dalam vii dan misi itu sering kurang dipahami suatu institusi. Akibatnya nilai-nilai itu tidak lebih dari sekedar pajangan di dinding ketimbang sebuah pahatan yang terukir jelas di hati dan pikiran para karyawan dan ekskutif.

\section{Simbol-simbol yang kasatmata}

Simbol sering disebut identitas perusahaan, apakah berbentuk logo perusahaan atau lambang lainnya. Nilai-nilai dan keyakinan di atas adalah sesuatu yang bersifat sulit dipahami oleh awam dan intangible. Nilai-nilai tersebut perlu diterjemahkan dalam simbol-simbol yang kasat mata, seperti logo, nama perusahaan, cara berpakaian karyawan, dan sebagainya. Simbol-simbol itu selain dimaksudkan agar lebih diingat oleh konsumen, juga agar dijiwai oleh segenap karyawan. Simbol ini menjadi lebih penting bagi perusahaan yang bergerak di sektor jasa yang menjaga pelayanan, kredibilitas dan keramahan manusia didalamnya. Contoh perusahaan yang menggunakan simbol adalah perusahaan rokok PT.Gudang Garam yang berkantor pusat di Kediri. Pada logo perusahaan tergambar sebuah gudang garam tua dengan dua pintu terbuka, dua lainnya setengah terbuka dan satu pinttu tertutup sama sekali. Menurut Almarhum Suryo Wonowijoyo (pendiri PT.Gudang Garam) logo itu menunjukan 
kerja keras yang tidk pernah berhenti. "kalau terbuka semua, kami beranggapan sudah usai,sudah puncak."

\section{Bahasa}

Banyak korporat yang menggunakan bentuk bahasa, seperti slogan, moto, filosofi, bahasa percakapan, dan bentukbentuk lainnya untuk memberikan arti tertentu kepada karyawannya. Bentuk-bentuk itu digali dari para pendiri yang berperan sebagai pimpinan spiritual perusahaan

\section{Ritual dan Seremoni}

Seorang Praktisi PR dapat mengembangkan budaya perusahaan melalui penggunaan cara cara tertentu (riual dan seermoni). Acara acara didesain dengan memberi bobot manfaat bagi para anggota perusahaan, sebab pada acara itut akan hadir segala lapisan poisisi dalam perusahaan dan hal ini merupakan kesempatan yang sangat baik bagi perusahaan untuk menanamkan suatu nilai. Budaya perusahaan dapat dikembangkan melalui penggunaan acara-acara tertentu seperti ritual dan seremoni. Ritual adalah sebuah kegiatan yang bersifat ekspresif dan dilakukan melalui serangkaian langkah serial yang konsisten secara rutin atau berulang-ulang.

Ada 4 (empat) macam bentuk ritus yang dapat dikembangkan oleh seorang PR : 


\section{Ritus Penerimaan.}

Acara Penerimaan ini didesain untuk memberi otientasi kepada anggota baru, sebagai masa transisi bagi seorang untuk memasuki nilai nilai sosial baru dan status baru.

\section{Ritus Penguatan}

Ritus ini diselenggarakan untuk mengingatkan seoang nbahwa ia telah memasuki kedudukan yang agak senior dalam perusahaan. Tujuannya adalah memperteguh identitas sosial dan meningkatkan status karyawan. Biasanya dilakukan dengan pemberian award tertentu.

\section{Rirus Pembaharuan}

Acara ini dilakukan dengan maksud meningkatkan kemampuan seseorang lewat suatu program pelatihan berjenjang yang sangat kompetitif dan berjangka cukup lama. Pembaharuan akan meningkatkan displin dan rasa telah melewati babak baru.

\section{Ritus Integrasi}

Dilakukan dengan maksud untuk menciptakan iklim dan perasaan kebersamaan diantara karyawan dan menimbulkan komitmen terhadapa organisasi ( misal mengadakan tour untuk seluruh anggota keluarga karyawan ke luar kota dalam kurun satu tahun sekal., mengadakan acara gathering disaat momen hari besar kegaamaan). 


\section{BAB V}

\section{MARKETING PUBLIC RELATIONS}

\section{A. Deskripsi singkat}

Bukan berarti PR tidak boleh menggunakan strategi periklanan. Baik publitsitas mapun periklananbersama sama digunakan public relations untuk mendukung tujuan marketing. Bedanya periklanan public relations lebih diarahkan untuk menjual citra perusahaan ( company/corporate image) bukan bersifat menjual produk secara langsung. Misalnya terlihat pada iklan institusi, iklan lowongan kerja,iklan pemberitahuan atau iklan pengingat (reminder).

Ini adalah konsekuensi tugas Public relations yaitu memberikan dukungan kepada marketing dengan menjaga faktor faktor di luar produk (anatara lain ; poltiik, supplier, distributor, sosial, agama, konsumen, lembaga keuangan,komunitas dd) agar tetap ramah kepada perusahaan. Pada akhirnya citra positif terhadap produk dan perusahaan akan menunjang penjualan produk.

Dalam bisinis global saat ini, Public relations dan marketing digunakan untuk saling mendukung . Dengan kata lain, prinsip prinsip public relations yang berupaya membangun citra produk dan perusahaan banyak diterpakan dalam strategi marketing. Meskipun antara Public relations dan marketing secara filosofis berbeda. Public relations bertujuan membangun citra 
(kepada target publik) sedangkan marketing bertujuan menjual produk ( Produk selling) kepada target market. Perpaduan antara dua elemen penting organisasi ini melahirkan konsep "Marketing Public Relations(MPR)".

\section{B. Kompetensi Dasar}

Mahasiswa dapat memahami dan mampu mengembangkan organisasi / perusahaan melalui Profesi PR

\section{Indikator}

- Mahasiswa mampu mendefinisikan Pemasaran dan penjualan.

- Mahasiswa mampu mengidentifikasi potensi perusahaan.

- Mahasiswa mampu mengembangkan perusahaan melalui marketing PR.

\section{MARKETING PUBLIC RELATIONS}

Konsep Maketing Public Relations (MPR) diperkenalkan oleh Thomas L.Haris dalam buku The Marketer's Guide to Public Relations. Menurut Haris, Makreting Public Relations bekerja karena ia memberi nilai tambah pada produk melalui kemampuannya yang unik dalam memberikan kredibilitas pada pesan produk. 
MPR didefinisikan sebagai sebuah proses perencanaan , eksekusi dan evaluasi program program yang mendorong atau menganjurkan pembelian dan kepuasan konsumen melalui komunikasi yang kredibel dalam menyampaikan informasi dan menciptakan impresi yang mengidentifikasi perusahaan dadn produknya dengan kebuthan, keinginan, perhatian, dan kepentingan konsumen. Dengan demikian, upaya menjual produk jangan hanya berdasarkan profit oriented tetapi juga consumer's oriented.

Perkembangan konsep MPR ini dimulai dari kesadaran perusahaan yangs selama ini mengalami sesuatu yang ganjil. Seringkali produk mereka tidak bisa menembus pasar - bukan karena pasar menolak - tetapi karena terdapat kelompok masyarakat ( kebanyakan non konsumen) yang menghalanginya. Kelompok ini biasanya dinamakan Bloking stakeholders.

Misalnya, kasus waralaba McDonald, dari sisi produk, siapa yang tidak kenal makanan cepat saji inii. Produk produk McDonald. Laku keras bukan hanya rasanya yang berselera, namun juga faktor nilai tambah produknya seperti makanan berkelas sosial tinggi dan cepat saji. Dari sisi harga, konsumen menganggap murah dan terjangkau. Dari sisi distribusi (place), konter konter McDonald termasuk perusahaan yang aktif berpromosi, termasuk iklan iklan di media massa. 
Namun keeempat bauran pemasaran tersebut seakan tidak ada artinya saat terjadi aksi anti Amerika di beberapa penjuru Indonesia. McDonald dianggap representasi penjajahan ekonomi kapitalis Amerika. Beberapa konternya dirusak bahkan disweeping massa, sehingga terpaksa ditutup. Konsumen pun takut berkunjung. Padahal McDonald Indoneisa adalah waralaba yang sepenuhnya dijalankan oleh putra asli Indonesia. Cuma Lisensinya saja dari Amerika. Artinya apa ? dalam pemasaran terdapat faktor faktor diluar bauran pemasaran yang berperan. Faktor faktor itu bisa berupa kebijakan pemerintah, kekuasaan , agama, buadaya, kelompok penekan, lembaga keuangan, media dll..

Dari contoh McDonald diatas dapat disimpulkan bahwa penjualan McDonald terganggu karena ada isu anti Amerika yang dilontarkan oleh kelompok muslim di Indonesia. Kelompok ini bisa disebut sebagai sekelompok penekan berbasis budaya dan agama. Pasarnya sendiri tidak bermasalah, tetapi stakeholder yang lain harus digarap. Untuk menanggulanginnya tidak ada cara lain, kecuali dengan strategi komunikasi agar terjadi saling pemahaman - Upaya ini hanya bisa dilakukan dengan pendekatan Public Relations.

Berdasarkan kenyataan ini, pakar pemasaran Philp Kottler mengusulkan ide Mega Marketing dengan memasukan tambahan unsur " $\mathrm{P}$ " dari bauran pemasaran konvemsional (4P). Unsur " $\mathrm{P}$ " 
yang baru tersebut adalah Public Relations. Kemudian konsep Mega Makeketing menjadi inspirasi bagi Thomas L.Haris untuk menelurkan konsep marketing Public Relations.

Alat dan teknik public relations yang sering digunakan untuk menunjang marketing dan sasaran penjualan suatu bisnis disebut "Komunikasi Marketing" atau " Marketing Public Relations". Staf PR yang bekerja dibidang ini biasanya tergabung dalam divisi marketing. Public relations yang berorientasi marketing dibentuk oleh suatu divisi baru, yakni "Komunikasi dan Marketing" (Wilcox,et.al.1992 :339).

Public Relations dapat memperluas peranannya dalam bidang pemasaran produk atau jasa pada akhir tahun 1970 an dan awal 1980 an di Amrerika Serikat. Banyak pengelola marketing menerapkan PR sebagai pendukung unsur promosi dalam marketing Mix (bauran promosi terdiri dari produk, price, place, promotions) (seitel 1992:215).

Masuknya bidang PR kedalam marketing, karena peningkatan kebutuhan dan minat konsumen, harga semakin kompetitif, perlu memperluas distribusi, banyaknya promosi dari produk/jasa sejenis.

Berubahnya cara marketing dengan memasukan PR kedalamnya, bagi dunia usaha di Amerika disebabkan ;

1. Adanya sikap kritis konsumen dan ketatnya pengawasan pemerintah. 
2. Penarikan berbagai produk, selalu menghiasi berita utama di media massa.

3. Adanya kesan negatif konsumen kepada setiap produk yang ditawarkan.

4. Perlunya pemasangan iklan dengan muatan yang mencerminkan kebuthan sosial dan tanggung jawab produsen.

5. Seringkali bermunculan berbagai isu produk dan perusahaan.

6. Masalah citra perusahaan dan produk yang selalu harus dipelihara dan ditingkatkan.

\section{KONSTRIBUSI PUBLIC RELATIONS PADA MARKETING}

Ranah Public Relations adalah komunikasi untuk membangun identitas dan citra korporat. Sedangkan pemasaran adalah upaya mempertemukan kebutuhan dan keinginan produsen dan konsumen akan produk atau jasa. Pemasaran merupakan proses perencanaaan dan pelaksanaan konsepsi, penetuan harga, promosi dan distribusi gagasan, barang, dan jasa utnuk menciptakan pertukaran yang memuaskan individu (konsumen) dan tujuan organisasi. Dengan demikian, ranah pemasaran berkaitan dengan bauran pemasaran, yaitu : 
1. Product, berkaitan dengan menjaga kualitas produk termasuk kemasan. Produk bisa berbentuk barang atau jasa.

2. Price (Harga), berkaitan dengan perumusan kebijakan harga untuk produk yang dihasilkan.

3. Place (tempat), berkaitan dengan saluran distribusi termasuk pemasok, agen atau grosir utnuk distribusi produk.

4. Promotions (promosi), adalah kegiatan mengkomunikasikan strategi mempromosikan produk. Promosi adalah kegiatan mengkomunikasikan tentang pesan pesan produk, harga dan saluran distribusi. Karenanya bisa disebut sebagi komunikasi pemasaran. Jenisnya antara lain periklanan, promosi, penjualan, dan personal selling

Ini adalah konsekuensi penerapan konsep startegis pemasaran dalm aktivitas perusahaan. Konsep pemasaran mencakup tiga komponen, Pertama; adanya pemenuhan kebutuhan dan keinginan konsumen. Segala aktivitas perusahaan pengembangan produk, penentuan harga , dsb - mesti didasari oleh kebutuhan dan keinginan konsumen. Ini yang dikenal sebagai orientasi pada konsumen. 
Kedua; segala upaya pemasaran mesti terkoordinasi diseluruh organisasi sebagai kesatuan. Fungsi pemasaran harus satu suara dengan fungsi manajemen lainnya, seperti fungsi keuangan, pengembangan SDM, Public relations dsb. Tentu saja, kegiatan komunikasi pemasaran ini tidak dapat berjalan sendiri. Produk bukanlah sesuatu yang berdiri sendiri. Mempromosikan produk bukan hanya bicara soal bauran pemasaran saja, tapi jiuga dipengaruhi oleh faktor faktor lain- internal perusahaan atau eksternal. Faktor faktor itu bisa menyangkut pelayanan, perilaku organisasi,budaya, pemerintah, identitas korporat, citra korporat dsb. Ketiga ; adanya penvcapaian tujuan tujuan jangka panjang. Strategi pemasaran dimaksudkan bukan untuk mencapai tujuan sesaat tetapi diharapkan utnuk waktu yang lebih lama. Perusahaan harus berpikir untuk bisa bertahan dalam persaingan yang lebih berat.

Kontrsibusi PR paling dirasakan tatkala mengelola unsur eksternal atau pengesahan pihak ketiga, seperti komentar positif media, kesaksian pelanggan yang puas atau opini opini oleh kelompok kelompok tertentu. Pengesahan pihak ketiga ini memiliki dampak lebih kuat terhadap khalayak dalam hal kredibilitas . Biasanya pengesahan pihak ketiga ini berbentuk berita di media. Inilah publisitas.

Dengan memperoleh kredibilitas melalui pengesahan pihak ketiga (media), Public relations dapat : 
- Menciptakan lingkungan pasar yang kondusif

- Meningkatkan visibilitas dan atau share of voice

- Menginformasikan atau mendidik pelanggan

- Memengaruhi perdagangan dan mendukung daya jual

- Memberi pengaruh atau membentuk opini

- Memperluas promosi dan memperkuat iklan

- Mengeksploitasi sponsorship

- Mengelola permasalahan dan mengatasi krisis.

PR dapat menjadi efektif menopang fungsi marketing, harus terlebih dahulu diperjelas dalam perencanaan marketing. Perencanaan harus matang dalam menentukan sasaran dan target perusahaan, yaitu dengan penerapan strategi dan taktik promosi untuk penjualan suatu produk.

PR digunakan dalam perencanaan marketing untuk mencapai jumlah sasaran :

1. Membantu perusahaan dan nama produknya agar lebih dikenal.

2. Membantu mengenalkan produk baru atau peningkatan produk.

3. Membantu meningkatkan suatu produk life style contohnya menyempurnakan pesan iklan dan promosi penjualan dengan menambah informasi baru. 
4. Mencari pangsa pasar baru dadn memperluas keberadaannya.

5. Memantapkan semua image (citra yang positif bagi produk dan usahannya.

Begitu erat dan pentingnya kerja sama antara bidang Public relations dan marketing, sehingga ada istilah utnuk menggabungkan aktivitas keduannya yang disebut dengan Marketing Public Relations (MPR).

MPR memperkuat fungsi manajemen perusahaan dan mendukung tujuan pemasaran. Coorporate Public Relations (CPR) memiliki fungsi sebagai fungsi manajemen perusahaan dan mendukung tujuan perusahaan. Kaitan antara MPR dan CPR adalah suatu kemitraan yang saling mempengaruhi. Hal ini tifdak akan tercapai jika MPR dan CPR sama sama melihat sebagai lawan bukan sekutu.

Hermawan kartajaya, dalam bisnis Indonesia (23/11/1995),"Mengapa Perlu Power dan Public Relations,"mengatakan konsep Marketing Mix (produk,price,Place, promotion) pertama kali diperkenalkan oleh Jerome McCarthy, bukan Phlip kotler. Tapi seolah konsep itu diciptakan itu oleh Kotler, karena Kotler lah yang mempopulerkan marketing mix ini. Seperti halnya Sparry Rand, pembuat komputer pertama kali, tapi 
IBM yang mempepulerkannnya. Orang jadi lupa terhadap Sparry Rand dan hanya ingat bahwa komputer itu adalah IBM.

Dalam kasus marketing mix, Philip kotler lebih terkenal dibanding Jerome Mc.Charty. Kotler mungkin risih, akan menambah 2P dari marketing mix (4P) Menjadi 6P dan mempopulerkannya dengan istilah mega Marketing. Dua P dari Kotler adalah Power dan Public Relations. Kedua P biasanya dipakai kalau pasar belum diakses.

Power adalah penggunaan hubungan dengan kalangan birokrat supaya suatu market (yang tertutup) bisa diakses, sedangkan Public Relations adalah penggunaan hubungan dengan publik (masyarakat) luas supaya mendapat simpati. Jadi Power dan Publc Relations seperti kekuatan push dan pull yang bisa diapaki untuk melancarkan akses pasar yang terhambat.

Tapi Power juga bisa dipergunakan untuk tujuan lain ?.Apa itu justru untuk mem break suatu situasi monopoli. Sebenarnya Kotler dalam contoh contohnya power lebih merujuk pada situasi semacam itu. Kalau Power dipakai untuk mematahkan situasi monopoli, ceritanya amat berbeda. Lihatlah bagaimana suatu maskapai penerbangan swasta mematahkan monopoli Garuda, dan operator telepon selular mematahkan monopoli Indosat. Juga bagaimana stasiun TV swasta mematahkan monopoli TVRI. Tentu saja masalahnya berbeda dari sutau kasus dengan kasus yang lain. 
Sebagai misal, ambilah contoh; Sempati dan Satelindo punay posisi awal yang sangat "lemah" dibandingkan dengan Garuda dan Indosat. Sedangkan RCTI, justru dulu mendapat hak monopoli iklan televisi, karena TVRI justru tetap tidak boleh beriklan. Namun masa monopoli RCTI tidak bertahan lama, karena hak beriklan pun diberikan kepada televisi swasta lainnya seperti SCTV,AN TV, Indosiar dll. Inilah yang dikatakan Kotler , Power justru dipakai untuk menghidupkan mekanisme pasar.

Saat ini konsep mega marketing tidak populer lagi karena power semakin jarang dipakai, sementara Public Relations memang menjadi keharusan bagi semua perusahaan (Kartajaya.1995).

Sebagai PR yang tak luput strategi, MPR senantiasa memperhatikan strategi pemasaran, diikuti pengembangan sarana dan hasil secara langsnug berhubungan dengan pembelian dan penjualan. Namun diatas semua itu, yang paling penting adalah bahwa marketing selalu ditekankan pada titik pandang PR, yang melengkapi suatu blueprint (rencana inti kegiatan), yang sesungguhnya bisa diikuti oleh siapapun juga, baik berpengalaman ataupun tidak sama sekali dalam bidang pemasaran.

Prosedur prosedur PR dilukiskan guna mencapai tujuan strategis yang dalam banyak contoh adalah efektif serta lebih 
kuat dibanding pendekatan marketing tradisional. Yang menyoroti pentingnya peran PR dalam marketing communications mix.

Banyak para manajer tidak menyadari bahwa periklanan tidak bisa untuk mencapai segalanya, situasi pemasaran tertentu dapat menetralisir apa yang ingin tercapai melalui periklanan. Sementara situasi yang sama sebenarnya dapat ditangani secara efektif dan ekonomis melalui PR.

Menurut Kasali, pertanyaan yang sering mengacaukan bagi praktisi PR adalah PR ssama dengan marketing ? kalangan praktisi pemasaran dalam kurun liam tahun belakangan ini sering menilai bahwa kampanye PR merupakan suatu pengembangan baru bagi kampanye pemasaran. Pendapat ini memang tidak salah $100 \%$, karena Philip Kotler, tokoh sentral pemasaran yang buku buku teksnya diapakai luas diseluruh dunia, pernah menulis di dalam Havard Business Review bahwa PR merupakan bagian dari Mega Marketing.

Kotler percaya bahwa PR bersama konsep mega marketing mampu membuka negara negara yang tertutup. Kotler mendefinisikan mega marketing sebagai ; "Aplikasi koordinasi secara terencana atas unsur unsur ekonomi, psikologi, politik dan keterampilan PR untuk memperoleh simpati (kerja sama) dari piahk pihak yang terkait agar dadpat beroperasi atau masuk ke pasar tertentu. 
Pendapat ini pernah di[erdebatkan oleh para ahli PR, karena khalayak sasaran kedua konsep i9i sangat berbeda yang satu mempunyai sasran embak target market dan yang lain mempunyai sasaran target publik.

Untuk meluruskan perbedaan pendapat ini, ungkap KasaliThomas I. Harris, guru besar journalisme pada Kellog School Of Journalism mengembangkan konsep yang disebut MPR. Dengan melihat praktek praktek PR pada kegiatan "pemasaran", Harris menyarankan agar para praktisi dapat memisahkan kegiatan yang menjadi bagian dari marketing (MPR) dan bagian menjadi bagian Korporat (CPR).

Pengamatan dan konsep Harris ini menurut pendapat Kasali, sangat pemnting karena pemakaian konsep PR dalam pemasaran telah berkembang demikian pesatnya untuk mendorong kegiatan pemasaran. Menurut penelitian yang dilakukan oleh konsultan PR terkemuka Shandwiick pada tahun 1989, anggaran MPR berkisar dari seluruh biaya PR di seluruh dunia.

Untuk menghindari kerancuan berpikir, Kasali menggunakan konsep Harris sekaligus menempatkan siapa yang bertanggungjawab atas setiap kegiatan serupa di dalam suatu perusahaan. MPR adalah bagian dari kegiatan pemasaran, penanggungjawab tertingginya adalah manajer pemasaran dan 
objective dari kegiatan PR adalah mendukung objective dibidang pemasaran.

Untuk menjalankan kegiatannya, orang orang pemasaran bisa meminta bantuan CPR karena keahlian CPR memng murni dibidang PR. MPR dibawah manajer marketing, bergantung dari strukturnya bisa berada dibawah direktur utama, Presiden direktur atau CEO. Di negara negara maju, Manajemen/ Chief Executive Officer jauh lebih berkuasa dari pemilik saham, karena mayoritas umunya memiliki share dibawah 15\%. Di Indonesia, meski sudah go public konsentrasi itu masih ada, sehingga pemilik amat berkuasa. Sedangkan CPR adalah suatu staff khusus dibawah CEO atau direktur utama atau presiden direktur.

Mengapa CPR berada didekat CEO, presiden direktur utama? Karena CPR mempunayi tugas yang sangat sensitif, yakni menjaga kepuasan para stakeholder termasuk pemegang saham dan pemerintah lebih jauh lagi CPR bertanggung jawab terhadap pencegahan dan pemecahan krisis yang dapat mematikan perusahaan. Pekerjaan ini membutuhkan kedekatan CPR dengan pimpinan puncak, atau di Indonesia dalam hal ini pemegang saham mayoritas.

Dengan menggunakan pemikiran Harris, tugas seorang CPR akan lebih ringan karena sebagian pekerjaannya yang menyangkut consumer confidence and trust telah didelegasikan kepada bagian pemasaran (Kasali, 1994:11-14). 


\section{BAB VI}

\section{KUALIFIKASI PROFESI PUBLIC RELATIONS}

\section{A.Dekripsi singkat}

Benarkah Publik Relations mampu membentuk kepribadian ? kursus kursus Public relations yang ada selama ini sering menimblkan kebingungan para peserta. Puluhan bahkan ratusan gadis gadis cantik melamar untukk mengikuti kursus tersebut dengan harapan agar mereka ddapat menjadi praktisi PR yang mempunyai kepribadian, anggun dan tentunya luwes. Seminggu setelah mengikuti kursus, biasanya peserta tinggal separo. Menagapa?

Ketika kepada mereka ditanyakan apa sebabnya, ternyata mereka umumnya beranggapan bahwa kursus piblic relations tak lebih dari kursus kepribadian. Sebagian beranggapan bahwa kursus public relations identik atau setingkat di atas sekolah sekolah kepribadian atau sekolah modeling.

Tak banayak yang ahu bahwa public relations adalah suatu pendekatan yang sangat strategis yang menggunakan konsep konsep komunikasi . Dengan menggunkan teknik teknik komunikasi yang sesuai, praktisi public relations akan menjadi tenaga yang sangat penting bagi dunia usaha. Tentu saja semua ini ada hubungannya dengan kepribadian.

Roger Haywood, praktisi public relations terkemuka dari Inggris menyebutkan, bahwa organisasi atua perusahaan yang 
sukses tanpa public relations adalah sama dengan, katakanlah, seorang salesman, seorang politikus atau pengacara ( atau profesi pembujuk lainnya) yang berhasil tanpa kepribadian.

Jumlah diantara mereka yang berhasil tanpa kepribadian memang tidak sedikit. Tetapi Haywood kemudian melanjutkan ,"Sayangnya tak banak orang yang secara resmi alai mempunyai kepribadian posisitf, yang tidak perlu memikirkan sikanya, pendekatan pendekatannya atau perilakunya."

Kepribadian memang tetap merupakan modal penting untuk menjadi praktisi public relations. Tetapi lebih dari itu strategi jauh lebih penting. Stratgei itu meliputi cara cara membangun kepribadian perusahaan atau organisasi. Dengan kata lain seorang praktisi public relations harus bisa mentransfer pribadinya timbal balik dengan perusahaaan / organisasinya.

Kepribadian perusahaan secara menyeluruh dipengaruhi oleh banyak elemen, termasuk kepribadian praktisi PR itu sendiri. Elemen elemen pembentuk kepribadian perusahaan itu antara lain

1. Kepribadian dan perilaku pemilik dan para eksekutif puncak perusahaan.

2. Kepribadian dan perilaku para front liners.

3. Budaya Perusahaan. 
4. Hubungan anatara perusahaaan dan pihak pihak lain, misalnya pemerintah, konsumen komunitas, pemasok , bank, pasar dsb.

5. Karya karya yang dipublikasikan (iklan, artikel, slogan, pidato, surat dsb)

6. Identitas korporat (logo, desain Interior, eksterior)

7. Cara cara penanganan krisis.

Kepribadian tetap meemgang peranan yang sangta besar. Hanay ssaja kepribadian dan keluwesan praktisi PR saja tidak cukup. la membutuhkan wawasan, analisis, dan strategi utnuk menstransfer perusahaan kepada masyarakat .

\section{B. Kompetensi dasar :}

Mahasiswa dapat menjadi seorang PR

\section{Indikator}

- Mahasiswa mengetahui syarat syarat menjadi seorang humas (PR)

- Mahasiswa dapat mengevaluasi dan memahami tentang kemapuan dirinya untuk menjadi seorang humas (PR) 


\section{PERSYARATAN DASAR APA SAJA}

Teradapat lima persyaratan mendasar bagi seorang Humas (Public Relations) , seperti yang dikemukakan Jefkins (1998):

1) Abbility to Communicate (Kemampuan berkomuniasi)

2) Abbility to Organize (Kemampuan mengorganisasikan)

3) Abbility to get on with people (Kemmapuan bergaul/membina relasi)

4) Personal integrity (Kepribadian utuh/jujur)

5) Imagination (memiliki imajinasi yang kuat)

Berikut ke lima aspek kualifikasi profesi Public relations yang dikemukakan Jefkins :

\section{I.KEMAMPUAN BERKOMUNIKASI}

Mampu berkomunikasi dengan baik, terhadap orang yang memiliki aneka ragam karakter. Itu berarti harus mampu dan mau berusaha memahami, serta terkadang berusaha untuk bersikap setoleran mungkin keoada setiap orang yang dihadapinya tanpa harus menjadi penakut atau penjilat (jefkins,1996:21)

Kemmapuan berkomunikasi seorang PR ini secara lisan maupun tertulis, seperti Publik Speaking atau presentasi ( salah satu kemampuan komunikasi lisan di depan publik). Sedangkan penulisan press release dan mengelola media atau majalah perusahaan adalah kemampuan komunikasi tulisan.

Dalam aspek keilmuan, komuniaksi adalah induk ilmu daari bidang PR sedangkan dalam dunia PR komuniaksi merupakan 
tulang punggung (backbone) PR dalam melakukan berbagai programnya.

Kemampuan berkomuniaksi sebagai Communication is practice or communictions is art (sebagai komuniaksi praktis atau seni berkomuniaksi) mutlak dimilki oleh seorang Public relations offocer ( PRO ), dan tidak ada salahnya seorang PRO yang tidak berlatar belakang pendidikan komuniaksi/PR memahami pula communication is science (komunikasi sebagai sebuah ilmu).

\section{KEMAMPUAN MENGORGANISASIKAN}

Kemapuan mengorganisasikan dapat diartikan sebagai kemampuan memanajerial, yang dapat mengelola program PR mulai dari fact finding (pengumpulan data),planing (perencanaan), communicatting (mengkomunikasikan program), dan evaluatign (evaluasi program).

Kemampuan ini juga berarti mampu mengantisipasi masalah di dalam dan diluar organisasi atau perusahaan, serta mampu menyusun rencana kegiatan dan melaksanakan kegiatannya, termasuk pula membuat anggaran.

Kemampuan mengorganisasikan membuat seorang PR selalu berpikir,membuat rencana, membuat laporan dan mengevaluasi setiap program yang telah dijalankannya. Dalam melakukan aspek manajerial ini selalu didukung berpikir jernih dan bersikap positif ketika menghadapi permasalahan manajemen PR. 


\section{KEMAMPUAN BERGAUL/ MEMBINA RELASI}

Kemampuan ini dapat diartikan sebagai kemampuan menciptakan networking (jaringan) dengan berbagai pihak yang berkaitan dengan organisasi / perusahaan atau kegiatan PR itu sendiri. Berbagai unsur publik tentunya menciptakan hubungan yang lebih dalam dan akrab sehingga para relasi ini dapat mendukung berbagai program PR. Dalam membina relasi ini pun tentunya terjlain take and give antara keduanya dan terjadi huhbungan yang sinergi ntara PR dan berbagai unsur publik ini, yang tetap berlandaskan itegritas profesi.

Misalnya, untuk publik pers, seorang PRO mengenal lebih akrab tidak hanya wartawan, kalau perlu redaktur atau pemimpinredaksinya. Begitu pun dengan publik lainnya seperti pejabat tinggi pemerintah, tokoh masyarakat, pejabat legislatif, ppetinggi partai politik, tokoh LSM (Lembaga Swadaya Masyarakat) dan relasi lainnya, yang dapat memberikan dukungan terhadap kegiatan PR.

Kemampuan ini tentunya memerlukan keluwesan dalam bergaul dan selalu mencerminkan simpatik orang lain, sehingga orang lain, sehingga orang lain itu sangat wellcome ketika dihubungi maupun diajak kerja sama. 


\section{BERKEPRIBADIAN JUJUR}

Kejujuran hatrus tetap melandasi seseoramng yang menjadi profesi apapun, termasuk Public Relations (PR), karena aspek ini yang dapat membentuk kredibilitas (kepercayaan) orang lain terhadap PRO maupun perusahaan tempat PRO itu bekerja.

Banyak kasus yang mengakhiri kredibilitas seseorang dalam berbagai profesi, termasuk profesi PR, karena melupakan kejujuran. Kejujuran ini pula yang dapat membentuk kepribadian yang utuh bagi seorang PRO.

\section{MEMILIKI IMAJINASI YANG KUAT}

Profesi PR haruslah seseorang yang penuh dengan gagasan atau ide ide, mampu memecahkan problem yang dihadapi, mampu menyusun rencana yang orisinil dan dapat mengembangkan injainasi untuk melahirkan kreativitas kreativitas kerjanya.

Kreativitas ini bisa mencakup berbagai kegiatan seperti mengelola berbagai special events PR (pameran,workshop, seminar, press conference dII), pembuatan House Journal (media penerbitan PR), krisis manajemen dsb. Semua itu diperlukan pengamatan yang tajam, persepsi yang baik serta pemikiran yang orisinal dan perhatian penuh dalam mencari peluang peluang. Semua harus dalam kaitan pola komunikasi. (Jefkins 1988:36-39). 


\section{APAKAH ANDA MEMENUHI SYARAT ?}

Tugas humas (PR) dalam bidang apap pun, tidak akan membosankan, dari jam delapan sampai jam empat, selalu ada saja tugas yang membuat anda sibuk. Tidak jarang pula anda harus kerja lembur. Tak pelak lagi pad aacara tertentu hari libur pun anda harus masuk kerja.

Pekerjaan dibidang humas, tidak sama dengan pekerjaan lain pada umumnya. Hari hari kerja berlaku secara tak teratur. Tiap hari selalu berbeda, selalu ada kejutan dan problem problem baru untuk dipecahkan.

\section{Test Evaluasi Diri}

Profesi humas tidak selalu cocok bagi setiap orang. Untk bekerja dibidang humas diperlukan motivasi, kemmapuan dan kestablian emosi. Guna mengetahui apakah anda memenuhi persyaratan yang diperlukan unutk berprofesi humas, jawablah pertanyaan pertanyaan berikut ini dengan "Ya" atau"Tidak", kemudian lihatlah bagaimana hasilnya. Sisi pandang Profesi humas :

1) Dapatkah anda bekerja dibawah tekanan (underpreasure)?

Bila jawaban anda tidak, anda harsu menyangsikan kembali apakah humas benar benar profesi 
anda. Tidak seorang pun yang senang bekerja dibawah tekanan terus menerus. Walaupun begitu, itulah yang harus dihadapi oleh orang yang berprofesi humas.

Profesi humas disegala bidang selalu mengalami suasana kerja menegangkan. Ada orang mampu menghadapi tekanan sementara, ada pula yang tidak. Tekanan dapat melumpuhkan, bila anda tidak tahu cara menanggulanginya. Beberapa bidang pekerjaan memang ada yang memepunyai ketegangan lebih tinggi seperti periklanan, humas, wartawan/reporter dan pialang di bursa saham.

Tekanan maupun ketagangan sudah merupakan bagian dari tugas humas yang tak teralakan. Lebih baik mencari kata sepakat dahulu dengan diri sendiri, sebelum lebih serius anda memilih dan akan menekuni profesi humas.

\section{2) Apakah anda menyukai situasi yang penuh tantangan ?}

Dalam aspek humas yang mana pun, tantangan selalu menghadang di setiap langkah anda. Contohnya tugas humas suatu perusahaan berusaha memperoleh klien baru, tugas sebagai penghubung ntara organisasi/ perusahaan dengan klien. Penulis humas yang bertanggung jawab merencanakan kampanye, promosi, 
mempersiapkan berita pers dan prospektus/ selebaran seperti brosur.

\section{3) Dapatkah anda menerima kritik?}

Dalam proses meniti jenjang karir, anda harus siap menerima kritik dan mengambil hikmahnya. Seperti penulis yunior akan memerlukan waktu berjam jam hanya untuk mempersiapkan sebuah press release (pemberitaan pers)Pada saat berita itu selesai dibuat, seringkali masih banyak yang dikoreksi dan kadang kadang ditulis kembali oleh anggota staff senior dan akhirnya menjadi pemimpin.

Tidak semua orang ddapat menerima kritik, denagn cara yang sama. Ada orang yang tidak bisa membuang egonya dan menerima kritik, merupakan bagian yang penting dari tugas humas.

\section{4) Apakah nda seorang yang mampu mengorganisasikan?}

Dalam perusahaan dan bekerja dibidang humas, anda dapat mengerjakan berbagai pekerjaan secara bersamaan. Merencanakan, mengkoordinasikan dan mengorganisasi adalah penting. Pada perusahaan manapun dibidang humas anda bekerja, selalu akan anda jumpai kesulitan organisasi. 
Bidang humas memang membutuhkan orang orang yang mampu menciptakan suatu sistem yang fleksibel dan dapat dilaksanakan. Tanpa adanya sistem dan organisasi yang baik, anda akan terperangkap dalm kekacauan. Anda tidak akan pernah menyelesaikan sesuatu tepat pada waktunya.

\section{5) Apakah anda bekerja dengan baik bersama orang lain ?}

Humas merupakan bisnis masyarkat . Sepanjang hari anda akan berinteraksi dengan masyarakat. Dalam suatu perwakilan humas, anda kan erat berhubungan dengan klien dan anggota staff lainnya. Setiap hubungan berbeda satu sama lain. Pada waktu bekerja dengan anggota staf, tujuan anda yaitu mnyelesaikan pekerjaan tepat pada waktunya dan sesuai dengan keinginan klien.

Dalam bekerja sama dengan orang lain , keluwesan, pengertian dan kepekaan adalah penting. Tugas anda yaitu mempertahankan hubungan ramah dan produktif. Tugas ini tidak selalu mudah dilaksanakan. Tidak semua klien mudah diajak bergaul. Mungkin ada klien yang percaya pada anda dan memasrahkan segala masalahnya, tanpa banyak komentar, tetapi anda juga yang terlalu banyak menuntut dan sulit diajak kerjasama. Anda harus mampu mengatasi mereka semua. 
Seorang priofesi humas yang berpengalaman tentu dapat bekerja sama dengan semua klien, tanpa mempedulikan kepribadian ataupun tuntutan mereka yang keterlaluan. Mereka harus menggunakan taktik dan diplomasi yang profesional, seperti halnya kata kata yang mereka gunakan untuk mempertahankan hubungan bisnis yang produktif.

\section{6) Apakaha anda cakap dalam berkomuniksi ?}

Orang yang berprofesi humas, komunikasi dengan berbagai cara yang berbeda. Kegiatan yang anda lakukan sehari hari mungkin anda menulis, berbicara dan mengoordiansi bermacam macam proyek.

Bergaul dan berbicara dengan orang lain, merupakan kegiatan rutin bagi orang orang humas. Mereka menguasai dan menyukai aktivitas ini. Namun ada diantara kita yang lebih berbakat dari alamiah, sementara bagi yang lain harus berusaha cukup lama untuk bisa lancar berkomunikasi dengan orang lain Dalam berkomunikasi ladang kala ada orang yang memerlukan waktu brtahun tahun untuk mengembangkan percakapan ini. 


\section{7) Apakjah anda memiliki imajinasi yang baik?}

Semoga jawaban anda adalah Ya. Anda harus siap mepergunakan imajinasi untuk merumuskan startegi yang paling tepat bagi tujuan klien anda.

Setiap produk dan pelayanan jasa, memerlukan strategi humas yang khusus. Tantangan yang harus dihadapi adalah dalam emikirkan kampanye "humas" yang cocok untuk klien anda.

8) Apakah anda peka terhadap perasaan orang lain?

Semoga jawaban anda juga Ya. Pad waktu bekerja sama dengan orang lain, anda perlu bersikap sensitif dan menghargai perasaan mereka. Orang yang berprofesi humas harus menjalin berbagai macam hubungan yang berbeda. Mereka harus erat bekerja sama denagn staf mereka sendiri, sebaliknya juga harus mempertahankan hubungan yang produktif serta profesional dengan klien mereka .

9) Mampukah anda menarik keputusan dengan segera dan kemudian melaksankannya?

Seorang penulis humas senior pernah menulis "pegawai humas haruslah seorang yang bertanggung jawab." Tidak ada kata kata yang lebih benar daripada kata kata ini : "Bertanggung jawab" berati mampu melaksanakan sesuatu dengan cepat dan efesien 
"Bertanggung jawab" juga berarti mampu melihat situasi , menganilisnya dan mengambil keputusan. Orang yang berprofesi humas yang berpengalaman selalu melaksanakan hal tersebut.

10) Apaka anda memiliki pertimbanagn yang baik ?

Disamping kemampuan mengambil keputusan, pertimbangan yang baik juga diperlukan. Anda merupakan tenaga ahli dalam merumuskan strategi serta menganalisis pasar. Orang yang harus membimbing klien anada membantunua mengambil keputusan. Pertimbangan dan pemahaman yang baik tentang pasar amatlah penting.

11) Apakah anda memiliki kecakapan dalam hal kepemimpinan?

Kecakapan dalam kepemimpinan merupakan modal dalam setiap pekerjaa, khususnya dalam bidang humas, Bilaman suatu keputusan penting harus diambil, mereka harus bisa memastikan bahwa keputusan tersebut dilaksankan demi kepentingan klien. Seing pula mereka mengkooordinasi promosi besar besaran yang diikuti ratusan orang, mengarahkan mereka dan membimbingnya hingga proyek tersebut selesai. 
12) Apakah anda seorang "penjual"yang baik?

Seorang humas harus memiliki ketrampilan menjual. Selain menjual produk, anda juga menjual layanan jasa dan menjual citra positif.

Sebelum melamar pekerjaan anda perusahaan dibidang humas, anda harus meyakinkan pihak manajemen bahwa anda adalah orang yang tepat untuk pekerjaan tersebut. Anda harus menunjukan kepercayaan dan keyakinan pada diri sendiri. Anda harus mampu menjual profesi anda. Bila pekerjaan tersebut telah berhasil anda dapatkan, usaha selanjutnya yang harus anda lakukan adalah mendapatkan klien baru dan mempertahankannya. Untuk melakukan semua ini diperlukan keterampilan "menjual"

13) Bersediakah anda bekerja dengan waktu yang teratur?

Betapa berbedanya peekerjaan dibidang humas, dibandingkan bidang lainnya. Hari hari dalam sepekan yang akan terlewatkan tidak dapat diramalkan sebelumnya. Seringkali anda akan bekerja normal dari pukul 8.00 wib hingga 16.00 wib. Tetapi sering pula harus datang 8.00 wib dan pulang pukul 19.00 wib., bahkan masuk kerja pada hari libur.

14) Apakahanda senang melaksanakan beberapa pekerjaan, secara bersamaan? 
Seorang humas yang sibuk, mau tidak mau akan terlibat pada beberapa proyek, pada saat yang bersamaan. Pekerja dibidang humas menyukai kesibukan, meskipun kekacuan dan kekalutan kadang kadang menghadang langkah, namun mereka tetap berhari hari terlewatkan tanpa kesibukan. 


\section{KESIMPULAN}

Manajemen PR ( Publik relation ) dapat dikatakan sebagai penerapan fungsi-fungsi manajemen (perencanaan, pengorganisasian, penstaffan, pemimpinan dan evaluasi) dalam kegiatan-kegiatan humas. Manajemen humas berarti melakukan penelitian, perencanaan, pelaksanaan dan evaluasi terhadap berbagai kegiatan komunikasi yang disponsori oleh organisasi. Betuk kegiatan komunikasi bisa berupa kegiatan kecil sampai pada kegiatan yang sangat komplek seperti konferensi pers dengan menggunakan satelit.

Dengan melihat proses peranan manajemen dan hubungan masyarakat (humas) dalam suatu organisasi yang sudah dikemukakan, dapat dikatakan bahwa manajemen itu adalah upaya menyusun sasaran dan kerja sama melalui orang lain. Disamping itu, untuk dapat mencapai tujuan organisasi secara efisien dan efektif dan agar pekerjaan terlaksana dengan baik. Fungsi dan tanggung jawab manajer humas hendaknya mengupayakan terjadinya hubungan yang lancar dan efektif antara semua bagian dalam perusahaan disatu sisi dan antara perusahaan itu dengan publik internal dan publik eksternal.

Fungsi petugas PR atau PR Officer (PRO) pun berkembang seiring kemajuan dunia usaha. Ada 4 fungsi utama yang dituntut dari 
petugas PR, yaitu : Communicator, Relationship, Management backup, Good image make.

Komunikasi manajemen adalah hal yang paling pokok atau nomor satu, hal ini sesuai dengan pendapat GR Terry "Management is a communication", yaitu dalam hal penyampaian instruksi di satu pihak, dan pelaksanaan kewajiban di lain pihak. Dengan kata lain manajemen komunikasi adalah alat, bukan tujuan dari suatu organisasi. 


\section{DAFTAR PUSTAKA}

1. Rhenald khasali. Manajemen Public relations. Pustaka Utama Grafiti.2005.

2. Soleh Soemirat,Prof.,Dr dan Elvinaro,Drs.,M.S. Dasar dasar Publik Relation.Remaja Rosdakarya.2008.

3. Anne Gregory. PR dalam Praktek.Gelora aksara Pratama.2004.

4. Scot M.Cutlip,APR,PRSA,Fellow.Allen

H.Center,APR,PRSA, Fellow and Glen M.Broom,Phd.. Effetive PR.Kencana Media Group.2006

5. Firsan Nova.Re Public PR.Media bangsa.2012.

6. Rachmat Krisyantono. $\boldsymbol{P R}$ writting. Kencana Media.2008 
